NBER WORKING PAPER SERIES

\title{
JUST ABOVE THE EXAM CUTOFF SCORE: ELITE COLLEGE ADMISSION AND WAGES IN CHINA
}

\author{
Ruixue Jia \\ Hongbin Li \\ Working Paper 28450 \\ http://www.nber.org/papers/w28450 \\ NATIONAL BUREAU OF ECONOMIC RESEARCH \\ 1050 Massachusetts Avenue \\ Cambridge, MA 02138 \\ February 2021
}

\begin{abstract}
We are grateful to the China Data Center of Tsinghua University and the 90 universities in the survey for their collaboration. We thank Christopher Walters, anonymous referees, Nick Bloom, Raj Chetty, Aimee Chin, Julie Cullen, Joe Cummins, Gordon Dahl, Pascaline Dupas, Esther Gehrke, Eric Hanushek, Gordon Hanson, Wei Huang, Erzo Luttmer, Craig Mcintosh, Karthik Muralidharan, Nancy Qian, Zhuan Pei, Molly Roberts, Scott Rozelle, Eric Wang, Daniel Xu, Noam Yuchtman, Xiaoxue Zhao, Katia Zhuravskaya and seminar/conference participants at Berkeley, CIFAR, Cornell, Dartmouth, Fudan, George Washington University, Harvard, HKU, NBER, NEUDC, NUS, PacDev, Paris School of Economics, University of Houston, Sam Houston State, Stanford, Tsinghua, UC Riverside, UCSD, and Yale for their comments. Bingbing Li provided excellent research assistance. The views expressed herein are those of the authors and do not necessarily reflect the views of the National Bureau of Economic Research.
\end{abstract}

NBER working papers are circulated for discussion and comment purposes. They have not been peer-reviewed or been subject to the review by the NBER Board of Directors that accompanies official NBER publications.

(C) 2021 by Ruixue Jia and Hongbin Li. All rights reserved. Short sections of text, not to exceed two paragraphs, may be quoted without explicit permission provided that full credit, including () notice, is given to the source. 
Just Above the Exam Cutoff Score: Elite College Admission and Wages in China

Ruixue Jia and Hongbin Li

NBER Working Paper No. 28450

February 2021

JEL No. H1,I20,I25,I26

\begin{abstract}
$\underline{\text { ABSTRACT }}$
A burgeoning literature has documented the importance of elite colleges. Yet, little is known about access to elite education and its labor market implications in China, a country that produces one in every five college graduates in the world. College admission in China is governed by a single exam - the national college entrance exam, and the government sets admission cutoff scores for elite colleges. We examine the impacts of scoring above the elite-tier cutoff on a student's access to elite colleges and wage outcomes after graduation, using the discontinuity around the cutoff score. By employing hand-collected survey data, we find that scoring above the cutoff not only increases the chance of entering an elite college but also raises a young person's first-job wages after graduation. We also find that those just above the cutoff have peers with higher scores and better social networks than those below the cutoff, but it is less clear whether the two groups use their time differently in college.
\end{abstract}

Ruixue Jia

School of Global Policy and Strategy

University of California at San Diego

9500 Gilman Drive \#0519

La Jolla, CA 92093

and NBER

rxjia@ucsd.edu

Hongbin Li

Stanford Institute for Economic Policy Research

366 Galvez St

Stanford

Stanford, CA 94305

lihongbinsem@gmail.com 


\section{Introduction}

Access to education, especially elite education, is believed to be one of the most important channels for social mobility in modern societies. In economics, there exists a burgeoning literature on access to and the impacts of elite education in different countries including the United States (e.g., Dale and Krueger 2002, 2011, Hoekstra 2009, Hoxby 2009, Chetty et al. 2020), Chile (Hastings, Neilson, and Zimmerman 2013, Zimmerman 2019), Norway (Kirkeboen, Leuven, and Mogstad 2016), Italy (Anelli 2020), and India (Sekhri 2020). In this paper, we study access to elite colleges and its labor market consequences in China. Although China produces one in every five college graduates in the world and has massively expanded college enrollment since 1998, elite education remains out of reach for most Chinese students. ${ }^{1}$ For instance, in 2018, 81\% of China's 9.7 million exam takers were accepted by a college, but less than $5 \%$ were admitted by the Top-100 colleges.

Despite the country's college education scale and the well-known formidable national college entrance exam (known as Gaokao) that regulates access to different tiers of colleges, few empirical studies exist on elite education in China. One challenge is data availability. We are not aware of any existing large-scale data on labor market outcomes of college students that can be linked with the students' exam performance. The other challenge is identification; students admitted by elite colleges are likely to differ in ability and family background, which confounds the analysis of elite education.

In this paper, we use an institutional feature in college admission - elite college cutoff scores to study elite college admission and its implications for wages. The Chinese government divides the country's over 2,000 colleges into three groups, national first-tier colleges (roughly equivalent to the Top-100, defined as elite colleges in this paper), provincial and local four-year colleges, ${ }^{2}$ and tertiary vocational colleges, and sets cutoff scores for elite college admission. We explore the discontinuity generated by the cutoff score and compare outcomes of students immediately above and below this score to address the identification challenge of whether students in elite colleges are systematically different from their counterparts in non-elite colleges.

To overcome the data challenges, we conducted annual surveys of college graduates at 100

${ }^{1}$ With college expansion, the number of students admitted by some college rose from 1.1 million in 1998 to 7.9 million in 2018. The college expansion, however, concerns mainly non-elite colleges.

${ }^{2}$ Some of the provincial colleges belong to the provincial-level first-tier, which complicates our definition of elite colleges. We examine whether including them as elite colleges affects our findings. 
colleges (randomly selected from all colleges in China and stratified by location and college tier) between 2010 and 2015. Thanks to the collaboration of 90 of these 100 sampled colleges, we collected data on approximately 40,000 students from all 31 mainland provinces who attended colleges across 26 provinces. From this survey, we collected information on each student's college entrance exam score, first-job outcome, individual and parental characteristics, and behaviors and performance in college. We combine our survey data with hand-collected data on first-tier college cutoff scores from publicly available administrative records. We also supplement our survey data with administrative Gaokao data for one year, ${ }^{3}$ which can help us to assess potential sampling and measurement biases of our survey data. Finally, we obtained a large data set of job histories from an online recruiting platform to show that first-job outcomes have persistent effects.

Our survey data show a clear discontinuity in the probability of elite college admission around the elite college cutoff point. As a baseline, we analyze the 10,335 individuals within a bandwidth of 20 points (out of a maximum 750 points from six subjects) around first-tier cutoff scores. ${ }^{4}$ Employing both unweighted and weighted methods (the latter of which weights the data to reflect the population data), we find that scoring above the cutoff raises the admission probability by 16-18 percentage points, about $75-85 \%$ of the mean probability ( 21 percentage points). When using the administrative data, we find that scoring above the cutoff raises the admission probability by 22 percentage points, not far from the estimate that uses our survey data. A few institutional features account for why the magnitude is far from 1 . First, the elite cutoff score set by the government $e x$ ante is the minimum score for elite college admission, but the admission score of each college ex post is usually higher. Second, because thousands of students with the same score are competing for a few slots in each college, they are given only a few days to apply, and because each student can be accepted by only one college at most, the college admission process exhibits a high degree of uncertainty. As a result, it is expected that a sizable share of students who score above the cutoff will not be admitted by elite colleges.

Scoring above the cutoff also may lead to outcomes other than the opportunity of applying to an elite (national first-tier) college. In particular, there are also a few local colleges that are counted as first-tier in the local provinces in admissions. To examine how sensitive our results are, we use a broader definition of elite colleges that includes both the national and local first-tier colleges. The estimated discrete jump of the probability of elite admission does not change much with this broader

\footnotetext{
${ }^{3}$ There are no labor market data that can be linked with the administrative college admission records, which enhances the value of our survey.

${ }^{4}$ The optimal bandwidth, using the Imbens-Kalyanaraman (2012) method, is 21 points and for the Calonico-CattaneoTitiunik (2014) method, is 28 points. Our estimates are very similar when we use both bandwidths.
} 
definition, suggesting that the discrete jump is driven mainly by access to national first-tier colleges rather than local ones. In addition, students' majors and ranks in college - downstream consequence of elite college attendance - also may be affected. We find that scoring above the cutoff is weakly more likely to be associated with majoring in the humanities (compared with more competitive fields, such as economics, finance, law, and STEM) and has a greater likelihood of being ranked toward the bottom in college.

Despite these disadvantages in majors and college ranking, we find that those who score above the cutoff receive a 5.2-9.7\% higher wage offer for their first job after college, based on unweighted and weighted methods. We also find that this wage premium cannot be simply explained by industry, occupation or job location. Using a different dataset, from an online recruiting platform, we further document that the first-job wages matter in the long run, suggesting that our finding for the first-job wage premium is not likely to disappear over time. The reduced-form estimate on wages, together with the discrete impact of scoring above the cutoff for elite college admission, implies that attending an elite college increases the average monthly wage by $28-45 \%$ of the mean monthly wage based on an instrumental variable (IV) approach. To have a valid IV, we need to assume that scoring above the cutoff score is uncorrelated with wage, except through increasing the probability of first-tier admission. Although scoring above the cutoff can affect margins other than those related to attending a national elite college, we do not find strong evidence that the other margins are quantitatively important, which appears to validate our assumption. Thus, we present both reduced-form and IV results, which allows readers to judge which one is more meaningful.

Our resulting estimates add to a growing literature on elite college education. The implied wage premium for elite education in our setting is comparable in magnitude to estimates from other countries. For instance, Hoekstra (2009) studies one flagship state college in the United States and finds a $20 \%$ earning premium for white men. Anelli (2020) studies one elite college in Italy and finds that having attended the college raises the graduate's yearly income by $52 \%$. We would like to emphasize that, unlike the higher education systems in other countries, China's colleges have a clear hierarchy determined and controlled by the government. The elite status of a college stems from government designation, not competition within the education market. Despite these differences, our findings are not dramatically different from some existing estimates, suggesting that it would be useful to investigate the similarities and differences between a government-led education system and a market-driven one in future work.

Although our survey approach has disadvantages compared with studies that use administrative data, it enables us to examine student behavior in college and sheds light on potential drivers of 
the wage effect of attending an elite college. We find that students above the cutoff have different peers: On average, their schoolmates have higher entrance exam scores and more advantageous parental background (measured by college education and political status of the parents). We do not, however, find clear evidence that those above the cutoff spend their time differently or achieve more in college (measured by various types of certificates earned in college). Although our findings do not deny that access to elite colleges can affect credentials, they do suggest that those above the cutoff can be rewarded even without such a channel. These findings contribute to understanding the relative importance of different channels that underlies elite college premium, which is still a matter of scholarly debate.

To the best of our knowledge, this is the first study of elite education in China that exploits important features in the college entrance exam system. ${ }^{5}$ This exam has long been considered the most important life-changing opportunity for students and their families in China. It also has long been argued to be a driver of a demanding parenting style that pressures children to attain high scores (e.g., Chen and Uttal 1988). Our study reveals that a few points in the exam do matter greatly, as those who enter elite colleges by the narrowest margins are indeed rewarded. Our findings can thus partly explain the massive resources spent by students, and their parents and teachers in preparing for this exam.

We describe the institutional background in Section 2, and introduce our survey and data in Section 3 . We present our main results for how elite college eligibility affects elite college access and wage premium in Sections 4 and 5, and we discuss suggestive evidence of one's own behavior and peer characteristics in college in Section 6. Section 7 concludes the paper.

\section{Background}

China's higher education is hierarchical. The central government designates all colleges into tiers, i.e., first-tier colleges at the top, followed by provincial and local four-year colleges, and finally tertiary vocational colleges. All colleges admit students based on their college entrance exam scores.

\subsection{College Entrance Exam and College Admission}

The college admission process can be described in four stages, as explained below. In Appendix Table A.1, we provide the dates for each stage.

${ }^{5} \mathrm{Li}$ et al. (2012) use the first wave of our data and document a sizable elite college premium, whereby they focus on correlations between college status and wage outcomes. 
1. The Exam Gaokao, or the national college entrance exam, is one of the most important institutions in China. As shown in Appendix Table A.1, all college applicants take the exam at the same time (around June 6-9 every year) in their residence province. Students, who have already been divided into social or natural science during the first year in high school, take the exam in either the science or social science track. There are six subjects in the exam, with a full score of 750 points for both tracks. All students must take Chinese (150 points), mathematics (150 points), and a foreign language (mainly English, 150 points). In addition, students in the social science track need to take history, geography and political science (100 points each), whereas students in the science track take physics (110 points), chemistry (100 points), and biology (90 points). Exams are written and graded by provincial education authorities. Thus, the exam scores are comparable only within a given province-year-track. ${ }^{6}$

2. Exam and Cutoff Scores Announced Students learn their scores about two weeks after the exam. Each province also announces an admission cutoff score for each tier and track, based on the distribution of the scores and provincial quotas assigned by the Ministry of Education. In 2015, the score announcement dates were June 23-25. As shown in Appendix Figure A.1, a large and increasing number of searches of "first-tier cutoff" on Baidu appeared during these days. To ensure that colleges can recruit enough students, the cutoff scores are set at 105-120\% of the admission quota in each tier.

3. College Application After knowing their individual scores and admission cutoff scores, students apply to colleges by completing a college preference form within a few days, e.g., June 25-28 in 2015. Normally, students can choose up to five different colleges (with an order of preference) and three to five majors in each college. A student also can indicate in the application whether he or she is willing to be assigned to a college with vacancies out of his or her choice set. Those students with scores above the elite college cutoff are eligible to apply for elite colleges. Eligibility, however, does not guarantee admission.

\footnotetext{
${ }^{6}$ We do not study those who go abroad for college in this paper, as those students often do not take the college entrance exam. In fact, it is reported that students go abroad to avoid this formidable test. See the report, "Applicants say they want to avoid the stress of studying for Chinese college entrance exam": http://www.chinadaily.com.cn/china/ 2013-06/07/content_16580626.htm. It is, thus, difficult to tell whether the prospect of studying abroad matters differently for elite and non-elite colleges. If a large number of students from wealthier families (who are more likely to score above the cutoff) in our sample had gone abroad, we would expect to see that the above-cutoff students come from poorer families, which is not true in the data.
} 
4. College Admission Finally, colleges take turns in admitting students based on scores. The period was July 18-August 1 in 2015. First-tier colleges recruit first, and second-tier colleges start only after all first-tier colleges finish recruiting. With the same ex ante eligibility cutoff, each elite college may have a different ex post minimum admission score depending on competition. A student is admitted by at most one college, and once a student is admitted, he or she can either choose to go to the college or decline admission and not enroll in any college that year. ${ }^{7}$

Two institutional features are important for the mapping between scoring above (or below) the cutoff and elite college access. First, it is possible that a small share of students with scores below the cutoff were eligible to apply to elite colleges with the help of additional points based on individual characteristics, such as having the ethnic minority status, being a child of a military casualty, or having exceptional talent in areas such as sports, music, or math. Because these extra points and efforts to get them are determined before the exam (and the scores and cutoff are announced), they are not dependent on scores or do not vary across the cutoff (see Appendix Table A.1). Second, a sizable share of students above the cutoff cannot be accepted by elite colleges. As discussed above, the elite cutoff score set by the government ex ante is the minimum score for elite college admission; this minimum is usually lower than the admission score for each college ex post. In addition, there exists a great deal of uncertainty, especially because students have only a few days to file the application, after learning their scores and each student can be admitted by at most one college. Even though student-college matching quality is beyond the scope of this study, our findings suggest great room for improvement in this area in this educational system. ${ }^{8}$

\subsection{Elite and Non-Elite Colleges}

We focus on the most common definition of elite colleges in China: the national first-tier colleges, i.e., the 96 colleges that fall under the first tier in the recruitment process across all provinces. This definition of elite colleges heavily overlaps with the Project-211 (meaning Top 100 in the 21st century) colleges, with the advantage that our definition has a clear eligibility score in college admission. Thus, one can roughly consider our definition as the Top 100 colleges in China. Approximately $5 \%$ of the students go to elite colleges each year.

A complication in the admission process is the existence of local first-tier colleges. Specifically, some provincial governments allow a few local colleges to admit in the first-tier group to help these

${ }^{7}$ Similar to the U.S. system, the first college semester starts in September.

${ }^{8}$ The system studied in this paper already has experienced improvement over an old system (in which both of the authors took the exam), whereby most provinces asked students to apply before knowing their scores. 
colleges to admit better-quality students. This might work because some students do not have full information about these colleges and they are pressured to make a decision within a few days. These colleges, however, also admit students in the second tier in home provinces. Outside the home provinces, they are treated only as the second tier. Thus, the first-tier cutoff is less likely to be binding for this group. We also conduct an analysis by including this group in the elite tier to check for robustness.

Little is known about the quality of Chinese colleges by the public or researchers. In the United States, colleges advertise metrics such as graduation rates, post-college placements, class sizes, and funding per student to attract students. In a centralized college recruitment system based on exam scores, Chinese students have to rely on limited official information when choosing colleges. This means that government designation is the most important information about college quality. We provide comparisons between elite and non-elite colleges in our survey based on limited information, in Appendix Table A.2. As seen in the table, elite colleges, on average, attract higher-score students and more students from other provinces and abroad.

Different from colleges in the United States, tuition and graduation rates are not important indicators that separate elite from non-elite colleges. Notably, the tuition fees are generally low, thanks to the public nature of most colleges. If anything, elite colleges actually charge slightly lower tuition fees. In our data, the average yearly tuition fees are RMB 5,020 (USD 700) for elite colleges, and RMB 6,196 (USD 870) for non-elite colleges. In addition, Chinese colleges have extremely low dropout rates, which is different from what is seen in many other countries. The college education system in China is known for being "strict entry, easy out," meaning that the entrance exam competition is fierce but graduation is almost promised once enrolled. We are not aware of any systematic data that reports graduate rates by individual colleges, but there are plenty of anecdotes, such as the report (Zhang 2019) titled, "The problem with Chinese universities? Not enough dropouts." Further, Marioulas (2017) writes that "China has one of the lowest college dropout rates in the world, with sources from the ministry of education, who state that less than $1 \%$ of students fail to complete their degrees". In 2011, the Beijing-based Mycos Institute estimated that China's college dropout rate is 3\%, while the number from the Ministry of Education is even lower, $0.75 \%$. Due to the low dropout rate, conducting surveys conditional on graduation is unlikely to induce any systematic bias in our estimates. 


\section{The Survey and Data}

We collect the first data from China on individual exam scores, admission results, and labor market outcomes. We designed and conducted the Chinese College Student Survey (CCSS), an annual survey of college graduates, and use six waves (2010-2015) of the data. The CCSS is implemented by the China Data Center of Tsinghua University (which was directed by one of the authors) in collaboration with the Institute of Higher Education.

\subsection{The Survey}

College and Student Coverage We randomly selected 100 colleges out of a list of all colleges in China that were stratified by location (Beijing-Shanghai-Tianjin, Northeastern China, Eastern China, Central China, and Western China) and tiers of colleges (Project-985, Project-211, provincial and local colleges, and vocational colleges). In the sampling process, we separate three metropolises (Beijing, Shanghai, and Tianjin) from the rest of China because these cities have an extremely large concentration of colleges, especially top ones. Following this way of sampling, we get colleges of different tiers for all regions across China. This also means that we oversampled elite colleges (which is our intention, as we focus on them) because there are fewer of them in the population.

Originally, we had planned to gradually roll out the survey and reach our target sample of 100 colleges by 2013 (the number of sampled colleges is reported in Appendix Table A.3). Only 65 colleges, however, actually participated that year. In addition, the survey became voluntary in 2014 due to an unexpected budget cut, meaning that only those colleges that could afford and were willing to participate in the survey were included in the 2014 and 2015 samples. As a result, fewer than 20 colleges participated in the survey in each of these two years. We use data for all years in our baseline analysis and also show that our results are robust to excluding the 2014 and 2015 data.

In total, 90 colleges from our sample participated in at least one year of the survey, 26 of which belong to the national first tier. ${ }^{9}$ Appendix Figure A.4(a) plots the spatial distribution of the 90 colleges by province. As expected, we surveyed more colleges from regions such as Beijing and Shanghai, where there are more colleges. Their students come from all 31 provinces across China (Appendix Figure A.4(b)).

Students in each college are randomly selected from a roaster of all graduating students in that college. For the first year (2010), we aimed to select 400 students per college and obtained an average sample of 319 students from each college. Our target was cut down to 200 in 2011-2013 due

\footnotetext{
${ }^{9} \mathrm{~A}$ total of 15 belongs to the local first tier, which we also examine in our analysis.
} 
to rising costs associated with the survey. In 2014 and 2015, participating colleges agreed to survey 400 students in each college. Most of these volunteering colleges intended to collect a sample that was large enough for them to conduct an analysis on their own.

Survey Administration and Response Rates We conducted the surveys in May and June of each year (from 2010 to 2015), considering that the students would normally graduate and start their first job in July. To carry out the surveys, we selected two to three survey administrators in each college. These administrators were typically responsible for student registration, teaching administration, or student affairs management. All survey administrators participated in several days of training in Beijing to ensure that they understood and were prepared to fulfill their responsibilities. To increase the response rate, we gathered all sampled students in a college in one location to complete the survey at the same time. Each student was asked to individually and anonymously complete the questionnaire. At the beginning of these surveys, students were told that the survey was for research purposes and that their personal information would be kept confidential. The completed questionnaires were then coded and mailed to Beijing for data entry and cleaning.

Overall, we have reasonably high response rates. Across the six rounds of the survey, we have a response rate of $69 \%$ for elite colleges and $78 \%$ for other colleges, and the difference between these response rates is not statistically significant ( $p$-value $=0.26$ ). The six rounds of survey give us a sample of 40,916 students, among which 34,733 reported complete information on their exam scores and the provinces where they took the exam, with similar missing probabilities for elite and non-elite colleges (13.5\% and 15.7\%, with a $p$-value of the difference $=0.15)$. In Appendix Figure A.6, we also report the correlations between missing scores and personal characteristics. As shown, the missing probability is not correlated with gender, age, rural status, or family income. Repeated exam takers have a six-percentage-points lower missing rate, and those whose parents hold college degrees have a two-percentage-points higher missing rate. We show that our sample around the cutoff is comparable in all of these personal characteristics.

Adjusting Weights Using Administrative Data We use the administrative data (see next subsection) to generate weights to correct possible bias of our sample. Ideally, we hope that, after weighting, each student in our sample carries the same weight that he or she should have in the population. We do this in two steps. Although we started by drawing a random sample, we cannot claim that the collaboration decision of a college was random (within this random sample). To mitigate this issue, in the first step, we adjust the college sample weight so that, after weighting, the probability of a 
college in each stratum that is being surveyed should be equal to the probability in the population. Specifically, we rank all colleges in the administrative data by their median admission score and divide them into strata of 30 . We then adjust the college sample weight so that after weighting, the probability of a college in each stratum that is being surveyed should be equal to the probability in the population (i.e., the total number of students of colleges in each stratum divided by the student population, calculated using administrative data). In the second step, we adjust student sampling weight. Because we sampled a fixed number of students from each college and student response rates vary across colleges, our student sample in each college is not proportional to the student population in the college. After weighting, the number of students in each college in our survey should be proportional to that in the administrative data. Indeed, as shown in Appendix Figure A.5, the probabilities of entering our surveyed colleges by scores (in the administrative data) are similar around the cutoff. We later test whether the weighted frequencies of scores in our survey are smooth around the cutoff and report weighted results together with unweighted ones in our analyses.

Key Information The survey instrument was designed by one of the authors in collaboration with other colleagues. We collected data on each student's major and (self-reported) academic rank. In addition, we asked students about their time use and several achievement measures in college to understand whether an individual behaves differently if accepted by an elite college. We also collected the demographic information of students, including gender, age, and pre-college rural or urban residency (known as Hukou), as well as rich information on family background including their parents' education, income, occupation, industry, and Chinese Communist Party (CCP) membership.

In addition, we collected detailed job market information. We know whether the students searched for a job and found one. We also asked about their plan upon graduation (work, go to graduate school in China, go abroad to study, or wait). In addition to wages, we asked for detailed information about the best-offer job, including its location, industry, occupation, and employer ownership.

\subsection{Supplementary Data}

We also draw on a few other datasets to supplement our survey data. First, we hand collected province-year-track cutoff points for the first-tier colleges from publicly available administrative records. Second, we employ administrative data on the college entrance exam and college admission in 2003, which can not only serve as a benchmark but also help us to gauge the importance of potential measurement and sampling biases. Finally, our surveys collect information only on the 
college graduates' job offer at the time of graduation. As a complement, we employ data from a major recruitment platform of around 300,000 individual job histories, allowing us to document the first job's importance for future outcomes and shed light on the long run impact of education.

\subsection{Summary Statistics}

Among the 40,000 graduating students whom we surveyed, 10,335 fall into the 20-point bandwidth above or below the cutoff score, which is the sample of our focus. We summarize the key variables for our analysis here and present the summary statistics in Columns (1)-(4) of Table 1. The table shows that those above and below the cutoff within the 20-point group are comparable in individual and family background information. In contrast and as expected, there exist general differences in parental background among students with different scores when not restricting the sample (Columns (5)-(6)).

Not every student searched for a job and found one. In our data, $74 \%$ of the sample searched for a job prior to graduation, of whom $73 \%$ received job offers. For those not working, 19\% planned to pursue graduate studies in China, and 3\% planned to go abroad. The shares of students with wage information above and below the cutoffs are very similar: $49.2 \%$ versus $48.7 \%$. For students with offers, the mean and median monthly wages were 2,733 RMB and 2,500 RMB, respectively. To minimize the influence of outliers, we exclude $5 \%$ of the data $(2.5 \%$ in both tails of the wage distribution) in our baseline analysis.

\section{Scoring Above the Cutoff and Elite College Access}

In this section, we first describe the research design for the discrete impact of scoring above the cutoff score on entering an elite college. We then present the score distribution and balance tests and the estimation results.

\subsection{Research Design}

To examine how an individual's exam score affects elite college enrollment, we use the following specification:

$$
\begin{aligned}
& \text { EliteCol }_{i, p, y, t r}=\alpha_{E} I\left(\text { Score }_{i} \geq C u t_{p, y, t r}\right)+\theta_{1} f\left(\text { Score }_{i}-C u t_{p, y, t r}\right)+ \\
& \theta_{2} f\left(\text { Score }_{i}-C u t_{p, y, t r}\right) \times I\left(\text { Score }_{i} \geq C u t_{p, y, t r}\right)+\lambda_{p, y, t r}+\varepsilon_{i, p, y, t r},
\end{aligned}
$$


where EliteCol Co, $, y, t_{\text {is }}$ a dummy that indicates whether individual $i$ in province $p$, year $y$, and (natural or social science) track $t r$ attends an elite college. We define elite colleges as the national first tier and report results by extending this definition to include those who belong to the local first tier. $S_{c o r} e_{i}$ indicates individual $i$ 's exam score. The cutoff score for elite colleges $\left(C u t_{p, y, t r}\right)$ varies by province-year-track. The indicator function $I\left(\operatorname{Scor}_{i} \geq C u t_{p, y, t r}\right)$ equals 1 if the score is above the cutoff.

We include a function $f\left(S_{c o r} e_{i}-C u t_{p, y, t r}\right)$ for the running variable $\left(\right.$ Scor $\left._{i}-C u t_{p, y, t r}\right)$, namely the distance between a student's score and the cutoff score. To ensure that our results are not driven by certain functional form of $f$, we employ both the local linear non-parametric method and the parametric method for this function. In the parametric case, we allow the function to differ across the cutoff score by including the linear-interaction or quadratic-interaction terms of $\left(\right.$ Score $\left._{i}-C u t_{p, y, t r}\right)$ with $I\left(S_{c o r} e_{i} \geq C u t_{p, y, t r}\right)$. We also control for province-year-track fixed effects $\left(\lambda_{p, y, t r}\right) .{ }^{10}$ To determine whether our survey sample represents the population, we report both unweighted and weighted results (so that each student in our survey carries the same weight that he or she should have in the population).

\subsection{Score Distribution and Balance Tests}

Before presenting the estimation results, we describe the score distribution and report the balance tests. We plot the distribution of scores within the 20-point window in Figure 1. Because we oversampled elite students, we need to weight the sample to reflect the population. We apply the McCrary test to examine the intercepts of the weighted-frequency differences around the cutoff and obtain a $p$-value of 0.256 , suggesting that we cannot reject the null hypothesis that there is no discrete difference in frequency around the cutoff.

We conduct the balance tests regarding individual and family characteristics. As shown in Appendix Figure B.1, there is no discontinuous jump at the threshold for gender, age, being a repeat exam-taker, living in rural areas before college, father's/mother's income, father's/mother's having a college degree, or father's/mother's being a CCP member. To confirm the graphical results, we also report formal estimates of a different version of specification (1), replacing the dependent variable EliteCol ${ }_{i, p, y, t r}$ with these characteristics. We first report the results from the parametric method with quadratic interactions in Table 2 and the results from the local linear method and weighted regressions in Appendix Table B.1. We then use these observable characteristics to predict wage

\footnotetext{
${ }^{10}$ All standard errors from parametric methods are two-way clustered at the college and province-year-track levels. The results are also robust to clustering at the college level only.
} 
outcomes and examine whether predicted wages exhibit any discontinuities around the cutoff score and find that there is no discontinuity around the cutoff score in any of these regressions. Finally, to check whether missing wages affect our results, we conduct the same balance tests using only the sample with wage information and find similar results (reported in Panel (b) of Table 2 and Appendix Table B.1).

\subsection{Results on Elite College Access}

College Outcome There is an obvious discontinuous jump in the probability of gaining admission to elite colleges around the cutoff score. Figure 2(a) plots the probability of attending a national first-tier college against the running variable of each exam score point in the raw data, focusing on the range of 20 points above and below the cutoff. The figure shows a notable discontinuity around the cutoff point: Below the cutoff point, the probability of attending an elite college is around 0.04 and is fairly stable across scores; above the cutoff point, the probability of attending an elite college ranges between 0.19 (for the score at the cutoff) and 0.43 (for 20 points above the cutoff). The difference between one point above and below the cutoff is about 0.15 . This magnitude is far from 1 due to the high uncertainty of admission for those with scores just above the cutoff scores. The results do not change much when we control for province-year-track fixed effects and examine the residuals in Figure 2(b), where we bin the scores by four points to reduce noise in the data.

As placebo tests, we explore the previous-year and the following-year cutoff scores in Figures 2(c)-(d). Supposedly, the admission scores change every year, and we should not expect to see a discrete jump at the previous-year and following-year scores. As shown in Figures 2(c)-(d), there is indeed no discontinuity when replacing the actual cutoff scores with the placebo cutoff scores. The finding of no discontinuity supports the notion that it is difficult for students to game the cutoff scores.

The regression results reported in Table 3 confirm the graphical illustrations. Column (1) provides the estimate from the local linear non-parametric method. Scoring above the cutoff increases the probability of entering elite colleges by 0.165 . We then report results from the parametric method: Column (2) adds province-year-track fixed effects and controls for the linear interaction terms, and Column (3) adds the quadratic interaction terms. We obtain similar results using both methods. Columns (4)-(5) contain the weighted estimates, which are slightly larger than the unweighted ones (around 0.18).

In addition, we use a broader definition of elite colleges that includes the 15 local first-tier colleges in our survey. As reported in Columns (6)-(10), we obtain similar estimates with this 
broader definition, suggesting that the discontinuity around the cutoff is driven primarily by access to the national first-tier rather than the local ones. This is consistent with the understanding that these local colleges admit students in both the first tier and second tier and, thus, the first-tier cutoff score is not binding for them. We conduct three additional checks in Appendix Table B.3 where we center on the local first-tier colleges and show no significant jump around the cutoff even if we investigate the patterns by individual social-economic status. ${ }^{11}$

Due to possible measurement errors, our estimate is likely to be downward biased. To gauge the magnitude of the bias, we conduct the same analysis using administrative data for all exam takers in 2003. As shown in Appendix Table B.2, the estimate is about 0.22, indeed larger than estimates from our survey data. This is still far from 1, however, consistent with the notion that being above the cutoff does not guarantee admission.

Major and Ranking in College Within a college, the degree of competition in admission differs across majors. In this context, economics, finance, law and STEM fields have been popular and, hence, are more competitive than humanities during the recruitment process. If students with scores just at or slightly above the cutoff choose an elite college, they are less likely to major in the more popular fields because spots in these majors tend to be filled by students with higher scores. Our results indeed show that scoring above the cutoff is weakly correlated with college majors, but the correlation is not always significant. As shown in Columns (1)-(9) of Table 4, scoring above the cutoff is negatively associated with majoring economics, finance and law, and positively associated with majoring in humanities fields (Columns (5)-(9)).

Students just above the cutoff also know that they would be the lower-ranked (higher-ranked) ones if accepted by elite (non-elite) colleges, and they may make choices that takes this into account. In the survey, we asked students about their perceived college class ranking. Perhaps predictably, over $46 \%$ of the students claimed to be in the top $20 \%$ of their class, whereas only $5 \%$ claimed to be in the bottom $20 \%$. Even with this self-reporting bias, there is a systematic difference around the cutoff: Those just above the cutoff are more likely to place themselves in the bottom $20 \%$ (see Columns (10)-(12) of Table 4).

Therefore, while scoring above the cutoff makes one eligible for elite colleges, it also brings potential disadvantages in terms of majors and college ranking, which can be considered downstream consequences of elite college attendance. In principle, one can imagine a negative wage effect of

\footnotetext{
${ }^{11}$ Although all these results reveal no big changes around the cutoff in regard to being accepted by the local first-tier colleges, we add a note of caution. For example, there could be differences in admission probability in more sought-after versus less sought-after second-tier colleges.
} 
scoring above the cutoff, biasing downward the estimated effect on elite colleges. We show next, however, that there is a clearly positive wage effect, indicting the importance of attending elite colleges.

\section{Scoring Above the Cutoff and Wages}

In this section, we present the wage estimates, and interpretations of our results in the context of estimating the return to attending elite colleges. We also discuss several potential biases to our results and possible solutions. Finally, we document the correlation between the first-job wages and future wages to show the importance of first-job wages.

\subsection{The Wage Estimates}

We estimate the reduced form wage equation as follows:

$$
\begin{aligned}
& \ln \text { Wage }_{i, p, y, t r}=\alpha_{W} I\left(\text { Score }_{i} \geq \text { Cut }_{p, y, t r}\right)+\theta_{1} f\left(\text { Score }_{i}-\text { Cut }_{p, y, t r}\right)+ \\
& \theta_{2} f\left(\text { Score }_{i}-C u t_{p, y, t r}\right) \times I\left(\text { Score }_{i} \geq C u t_{p, y, t r}\right)+\lambda_{p, y, t r}+\varepsilon_{i, p, y, t r},
\end{aligned}
$$

where the variables are defined in the same way as in equation (1). Our focus is the coefficient on the dummy term $\alpha_{W}$.

We find that there is indeed a discontinuity in wage and log wage at the cutoff score. Figure 3 provides a graphical illustration of the means of wage and log wage by exam scores after isolating province-year-track fixed effects. We see, similar to that for elite college enrollment, a discontinuity around the cutoff values for both wages and log wages, despite the results nosier than those for attending elite colleges.

The graphical results are confirmed by the regressions reported in Panel A of Table 5. As shown by the local linear non-parametric estimate (Column (1)), having a score above the cutoff raises the average monthly wage by $5.3 \%$. When we add province-year-track fixed effects and the linear interaction terms (Column (2)), and quadratic interaction terms (Column (3)), we obtain estimates of $5.9 \%$ and $6.7 \%$. The estimates from weighted regressions are $5.2 \%$ and $9.2 \%$ (Columns (4)-(5)).

We report the effect of scoring above the cutoff on elite college (national first-tier) admission for the sample with wage information ( Panel B of Table 5). The results are similar to those from the entire sample, reported in Table 3: Scoring above the cutoff increases the probability of attending an elite college by $0.15-0.18$. 
The ratio of the estimated coefficient of scoring above the cutoff on wages over that of elite college admission would be the instrumental variable estimate of the return to elite education, assuming that the exclusion restrictions are satisfied. Exclusion restriction conditions, however, may not be met in our setting, because scoring above the cutoff also could affect the probability of attending local first-tier colleges and have downstream impacts on major and class rank in college. Empirically, we do have some information on how each of these might bias our estimates. As we have shown above, the discrete jump at the cutoff is driven mainly by the access to the national first-tier colleges. Not considering the local first-tier colleges, thus, should not have caused a major bias in the estimate. There is indeed a discrete jump for major and college ranking, but both imply wage disadvantages for above-score students, suggesting that the estimated return to elite colleges would be downward biased. With these caveats, we also report the IV interpretations in Panel C of Table 5. These estimates imply an elite college wage premium around 28.3-45.6\%.

\subsection{Additional Results}

Employment Decisions Not every graduating student searched for and found a job, and thus we need to consider potential selection biases of observing wages. The fact that the shares of students with wage information above and below the cutoff are very similar (49.2\% and 48.7\%) suggests that the employment decision is balanced at the threshold. Nonetheless, we directly examine whether scoring above the cutoff affects post-graduation plans and job-search behaviors.

Regression results reported in Appendix Table C.1 show that scoring above the cutoff does not affect the probability of attending graduate school home (Columns (1) and (2)) or abroad (Columns (3) and (4)). The above-cutoff score dummy in these estimates is insignificant and close to zero. Interestingly, the above-cutoff students are more likely to report "waiting to decide" (Columns (5)-(6)), which may reflect their higher reservation value. Related to this finding, those above the cutoff are weakly less likely to search for a job immediately after college graduation, and the difference is not significant (Columns (7) and (8)). Overall, these results suggest that considering employment decisions is unlikely to change our estimates of wages dramatically.

Variation in the Wage Premium One may wonder wether the wage premium is mainly driven by above-cutoff students' having jobs in different industries, occupations, types of firm ownerships, or cities. To this end, we gradually include dummy variables for occupations, industries, types of ownership, and city location in our regression equation. The estimates presented in Appendix Table C.2. Since outcomes like occupation and job location are endogenous, it is difficult to interpret the 
changes in the coefficients across specifications. The takeaway is that the wage premium cannot be washed away when we further include these characteristics.

Measurement Error in Wages and Bounding Exercises We also may have measurement error in wages. Although we can use administrative data to gauge the measurement error in scores, no existing data can shed light on that in wages. Note that a systematic bias would require that those above the elite cutoff over-report their wages but those below, under-report. We cannot directly test this assumption but believe that this is unlikely to be the case in our data. Our survey was conducted individually and anonymously and, thus, students have no obvious benchmark wage information to form a bias toward any specific direction. In addition, the same bias also would predict an elite premium in other job characteristics and performance in college, which is untrue in the data (next section).

To see whether missing wages and possible measurement errors in wages matter greatly for our findings, we conduct two sets of bounding exercises. First, we report the bounding estimates following Lee (2009) to assess the impact of differential attrition. As reported in Columns (1)-(3) of Table C.3, we obtain reduced-form wage estimates that range from 5.3\% to 8.6\%.

It is difficult to know what determines missing wages. By assuming that elite students with the highest and lowest wages are more likely to misreport their wages, we can at least get a sense of how robust our findings are. Specifically, we report results by trimming the highest and lowest $10 \%$ in the wage distribution for the elite college graduates. We also check the robustness of the procedure by trimming data in samples of different bandwidths, i.e., 20-point, 10-point, and 5-point. As reported in Columns (3)-(9) in Appendix Table C.3, we obtain estimates that range from 6.2\% to $7.1 \%$, close to our baseline estimates. Together, these findings show that it appears difficult for measure errors to explain our main findings, even though they certainly exist.

Excluding Data in 2014-2015 Our survey became voluntary in 2014 due to unexpected budget cuts, meaning that only those schools that could afford and were willing to participate in the survey were included in the 2014 and 2015 samples. Although the weighting regressions help to mitigate the concern of the representativeness, we also check how robust our results are by excluding the data in these two years. The results are similar if we exclude the data of 2014 and 2015: Scoring above the cutoff raises the probability of attending an elite college by 16-21 percentage points and the first-job wage by 6.5-9.4\% (Appendix Table C.4). 


\subsection{The Importance of the First Job}

In our survey, we observe the characteristics of the first job that students have out of college, but we cannot follow students once they enter the labor market. Recent studies that use administrative data in the United States suggest that the first job plays an important role in determining future career outcomes. For instance, Carr and Wiemers (2016) show a large rank-rank correlation between the first-job wage and wages across an individual's career. Using a different approach, Oreopoulos, Von Wachter, and Heisz (2012) show that a macroeconomic shock at the time of college graduation also can have a persistent effect on labor market outcomes over the long-term. We are not, however, aware of similar studies in China.

To investigate the importance of an individual's first job within the context of our study, we collect the job histories of 304,021 individuals from a major online recruiting platform (zhaopin.com). On this website, individuals report their monthly wage for each job that they have ever held, using five wage categories (1 for below 1,000 RMB, 2 for 1,000-2,000 RMB, 3 for 2,001-4,000 RMB, 4 for 4,001-6,000 RMB, and 5 for 6,001 RMB and above), as well as information on occupation, industry, and firm ownership type. With this information, we can examine the correlation between an individual's first job and his or her future labor market outcomes.

To allow our results to be comparable to those of our main analysis, we focus on a sample of individuals who earned four-year college degrees. We employ the following specification to examine the correlation between one's first job and the future labor market outcomes.

$$
\text { Wage }_{i, c, t}=\alpha_{1} \text { Wage }_{i, c, 1 s t}+\alpha_{2} \text { Wage }_{i, c, 1 s t} \times \text { EliteCol }_{c}+\lambda_{c}+\gamma \mathbf{X}_{i, t}+\gamma^{\prime} \mathbf{X}_{i, t} \times \text { EliteCol }_{c}+\varepsilon_{i, c, t},
$$

where $W_{\text {age }} e_{i, c, t}$ indicates the wage rank of individual $i$ who graduated from college $c, t$ years after the start of the first job and $W_{a g} e_{i, u, 1 s t}$ is the wage rank of the first job. We also control for college fixed effects $\left(\lambda_{c}\right)$, age and gender, and allow their impacts to vary with elite colleges.

We find that the variation in the wage rank of one's first job can explain a large portion of the variation in the wage ranks of one's future employment. When we include only the first-job wage rank in the regression equation without any controls, we get an $\mathrm{R}^{2}$ value of 0.623 (reported in Column (1) of Table 6). The coefficient shows that a one standard deviation change in the first-job wage rank is correlated with a 0.73 standard deviation change in the wage rank over the next five years. The coefficient is similar after we control for age, gender, and college fixed effects (Column (2)). The effect also appears to be slightly stronger for individuals who had attended elite colleges (Column (3)). The impact becomes slightly weaker, when we examine the wage rank over the next 6-10 years (Columns (4)-(6)). These results suggest that our findings on the first jobs taken by 
individuals in our sample are likely to matter for their long-term employment outcomes.

\section{Behavior in College and Peer Characteristics}

In this section, we examine outcome variables other than wages and attempt to shed some light on why scoring above the cutoff is rewarded by the labor market. We focus on the behaviors and achievements of students in college and the social and economic backgrounds of their peers.

Behavior and Achievement in College We examine whether the above-cutoff students behave differently in college or have higher achievement. We measure behaviors of students by their time uses in college. In our survey, we asked students about their weekly time (in hours) spent on attending classes, studying outside of class, working, sports, entertainment, and the Internet. As shown by Panel (a) of Table 7, we do not find any conclusive difference in terms of time use, as the standard errors are large and the signs of the coefficients vary.

To measure the students' achievement in college, we use a set of credential variables that normally appear on student resumes. These include their English skills, measured by a national-level College English Test (CET), certificates in computer skills, professional expertise (e.g., Certified Public Accountant (CPA) or a license to practice law), vocational skills (awarded by the National Occupational Skill Testing Authority), and driving. As shown in Panel (b) of Table 7, there is no evidence to suggest that scoring above the cutoff is associated with higher achievement measures. If anything, students who score above the cutoff are less likely to get either a CPA or a license to practice law, which is consistent with the fact that these students were weakly less likely to major in economics and law.

Peer Characteristics In contrast with the results for one's own behavior above, we find that students above the cutoff have peers with better credentials and social and economic status. We employ three measures of peer characteristics: schoolmates' college entrance exam score, the share of schoolmates with parents who are CCP members, and the share of schoolmates with college-educated parents. We find that above-cutoff students have schoolmates who score 15 more points in the entrance exam (Columns (1)-(2) of Table 8) and who have parents that are more likely to be CCP members and hold college degrees (Columns (3)-(6)).

Together with the results on the wage premium, our findings suggest that the college entrance exam score matters for both the students and the labor market. For students of similar background 
around the cutoff, those who score a few points more are rewarded, with or without differences in their own credentials.

\section{Conclusion}

By linking the two most important institutions - the college entrance exam and college hierarchy - in Chinese higher education, our study complements existing studies on the returns to elite colleges in other contexts. The college entrance exam in China is often considered to be the test that determines the course of one's life. Yet, little is known about whether better exam performance actually changes a young person's job outcomes. In this study, we collect systematic data on exam performance and link it to access to elite colleges and labor market outcomes. Students prepare for years in the hope of entering the best possible college. This effort appears justified by the labor market, given the differences a few points could make.

Underlying the rewards of a few extra points is the hierarchical structure of the Chinese college system. In our survey, we asked college graduates about the main barriers they face in getting a good job. Approximately $10 \%$ of the students answered this open-ended question. The top three barriers that they cited were the tier of their college (36\%), their major $(14 \%)$, or a lack of experience $(6 \%)$, further suggesting that the hierarchical college system is endorsed by the labor market.

We find clear evidence that those just above the cutoff have peers with more advantageous social economic status. In contrast, we do not find strong systematic differences in terms of time use and achievement in college. One potential reason is that higher education institutions pay too much attention to entry selection but much less to exit quality control, though we are not able to empirically compare this education system with an alternative system that regulates exit (like the U.S. system). We thus hope that our findings also raise some new questions on college education in China and its comparison with other systems for future work.

\section{References}

[1] Anelli, Massimo (2020), "Returns to Elite College Education: a Quasi-Experimental Analysis", Bocconi University, Journal of the European Economic Association, forthcoming.

[2] Battistin, Erich, Agar Brugiavini, Enrico Rettore, and Guglielmo Weber (2009), "The Retirement Consumption Puzzle: Evidence from a Regression Discontinuity Approach,” American Economic Review 99(5): 2209-2226.

[3] Calonico, Sebastian, Matias D. Cattaneo, and Rocio Titiunik (2014), "Robust Nonparametric Confidence Intervals for Regression Discontinuity Designs," Econometrica, 82(6): 2295-2326. 
[4] Carr, Michael and Emily E. Wiemers (2016), "The Decline in Lifetime Earnings Mobility in the U.S.: Evidence from Survey-Linked Administrative Data", Mimeo.

[5] Chen, Chuansheng, and David H. Uttal (1988), "Cultural Values, Parents' Beliefs, and Children's Achievement in the United States and China", Human Development 31(6): 351-358.

[6] Chetty, Raj, John Friedman, Emmanuel Saez, Nicholas Turner, and Danny Yagan (2020), "Income Segregation and Intergenerational Mobility Across Colleges in the United States", Quarterly Journal of Economics, forthcoming.

[7] Dale, Stacy and Alan Krueger (2002), "Estimating the Payoff to Attending a More Selective College: An Application of Selection on Observables and Unobservables," Quarterly Journal of Economics 117(4): 1491-1527.

[8] Dale, Stacy and Alan Krueger (2011), "Estimating the Return to College Selectivity over the Career using Administrative Earnings Data,” NBER Working Paper \#17159.

[9] Davezies, Laurent, and Thomas Le Barbanchon (2017), "Regression Discontinuity Design with Continuous Measurement Error in the Running Variable," Journal of Econometrics 200 (2): 260-281.

[10] Hastings, Justine, Christopher Neilson, and Seth Zimmerman (2013), "Are Some Degrees Worth More than Others? Evidence from College Admission Cutoffs in Chile," NBER Working Paper \#19241

[11] Hoekstra, Mark (2009), "The Effect of Attending the Flagship State University on Earnings: A Discontinuity-Based Approach," Review of Economics and Statistics 91 (4): 717-724.

[12] Hoxby, Caroline (2009), “The Changing Selectivity of American Colleges," Journal of Economic Perspectives 23(4): 95-118.

[13] Imbens, Guido, and Karthik Kalyanaraman (2012), "Optimal Bandwidth Choice for the Regression Discontinuity Estimation," Review of Economic Studies: 79(3), pp.933-959

[14] Kirkeboen, Lars, Edwin Leuven and Magne Mogstad (2016), "Field of Study, Earnings, and Self-Selection," Quarterly Journal of Economics, 131(3), 1057-1111.

[15] Lee, David S. (2009), “Training, Wages, and Sample Selection: Estimating Sharp Bounds on Treatment Effects," Review of Economic Studies 76(3): 1071-1102.

[16] Li, Hongbin, Lingsheng Meng, Xinzheng Shi and Binzhen Wu (2012), "Does Attending Elite Colleges Pay in China", Journal of Comparative Economics, 40: 78-88.

[17] Marioulas, Julian (2017) "China: A World Leader in Graduation Rates" International Higher Education 90: 28-29.

[18] Oreopoulos, Philip, Till Von Wachter, and Andrew Heisz (2012), "The Short-and Long-term Career Effects of Graduating in a Recession," American Economic Journal: Applied Economics, 4(1): 1-29.

[19] Sekhri, Sheetal (2020), "Prestige Matters: Wage Premium and Value Addition in Elite Colleges," American Economic Journal: Applied Economics, forthcoming.

[20] Zhang Duanhong (2019),'The Problem with Chinese Universities? Not Enough Dropouts," link here: https://www.sixthtone.com/news/1003440/the-problem-with-chinese-universities\%3F-not-enough-dropouts

[21] Zimmerman, Seth (2019), "Elite Colleges and Upward Mobility to Top Jobs and Top Incomes," American Economic Review 109 (1): 1-47. 
Figure 1: Weighted Frequency of Exam Scores in the Survey Data

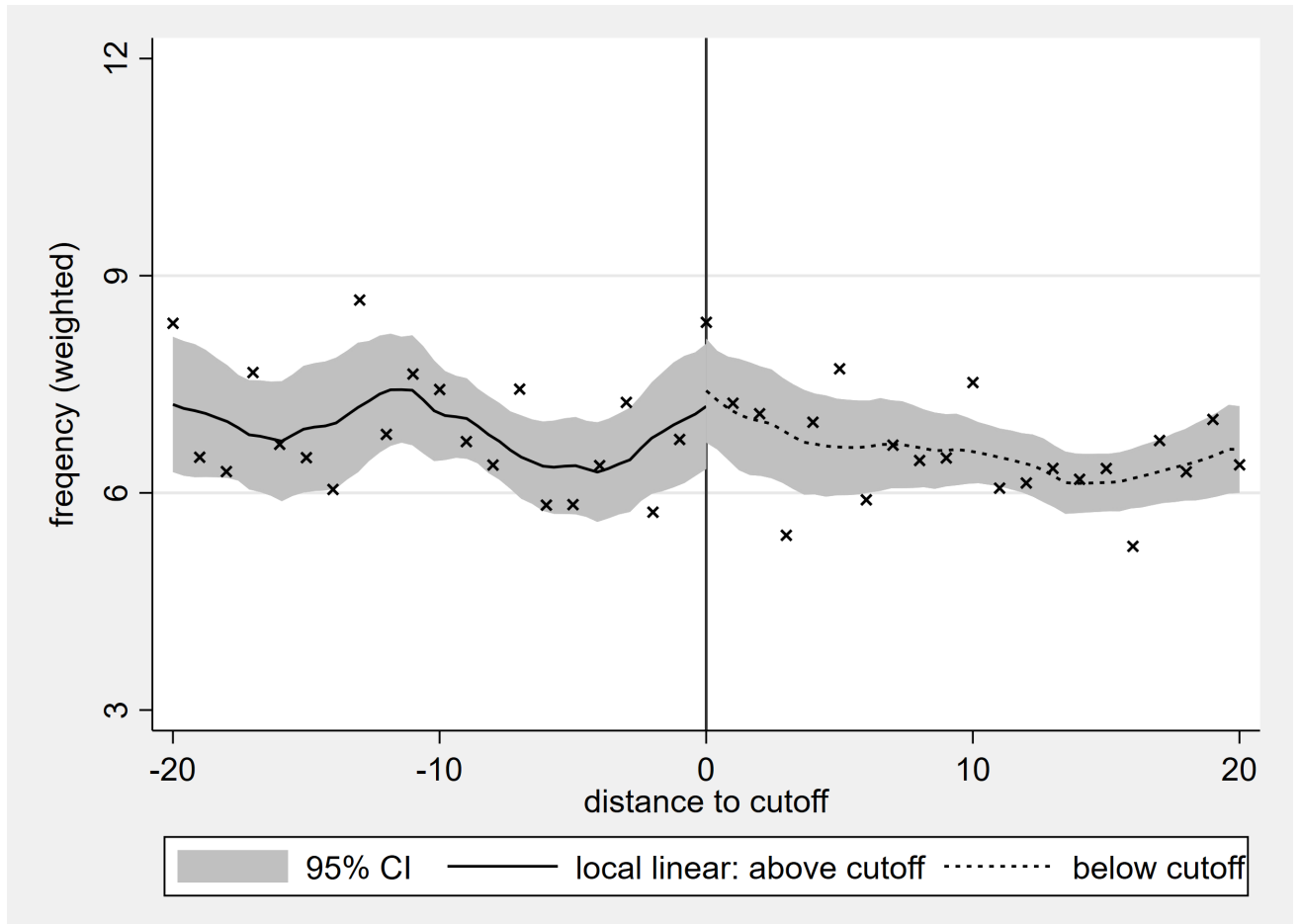

Note. This figure plots the distribution of exam scores in our survey data, after reweighting to reflect the population data. As shown by the local linear estimates, the difference in the frequency around the cutoff is insignificant. 
Figure 2: The Probability of Elite College Enrollment vs. Distance to Elite College Admission Cutoff Scores

(a) Raw Data

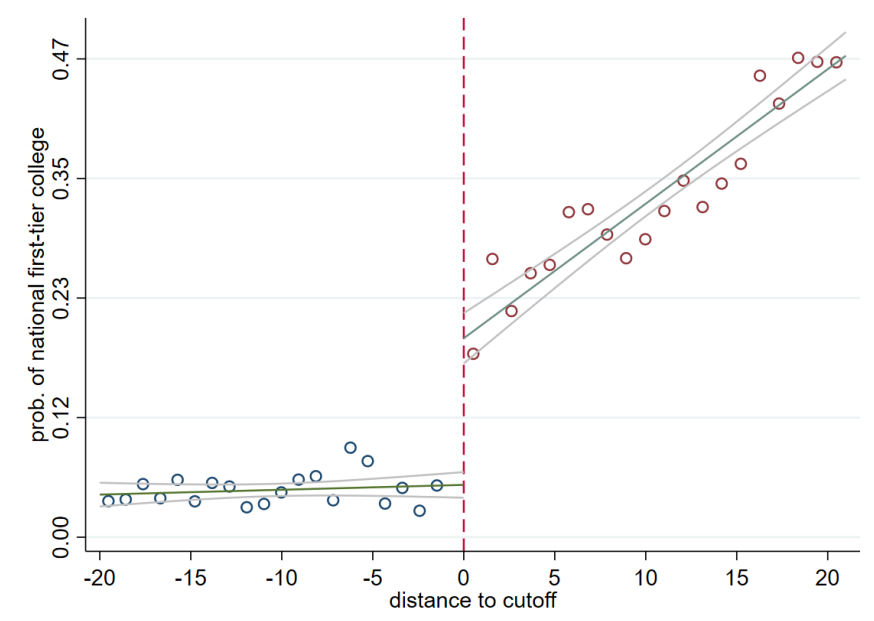

(c) Placebo I: Using previous-year cutoffs w. Pr-Ye-Tr FEs

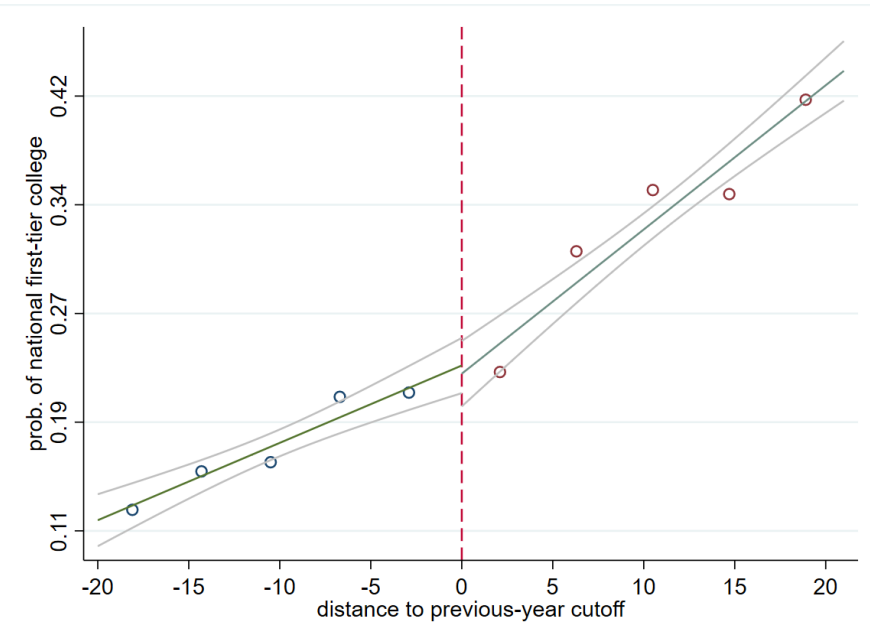

(b) With Province-Year-Track FEs

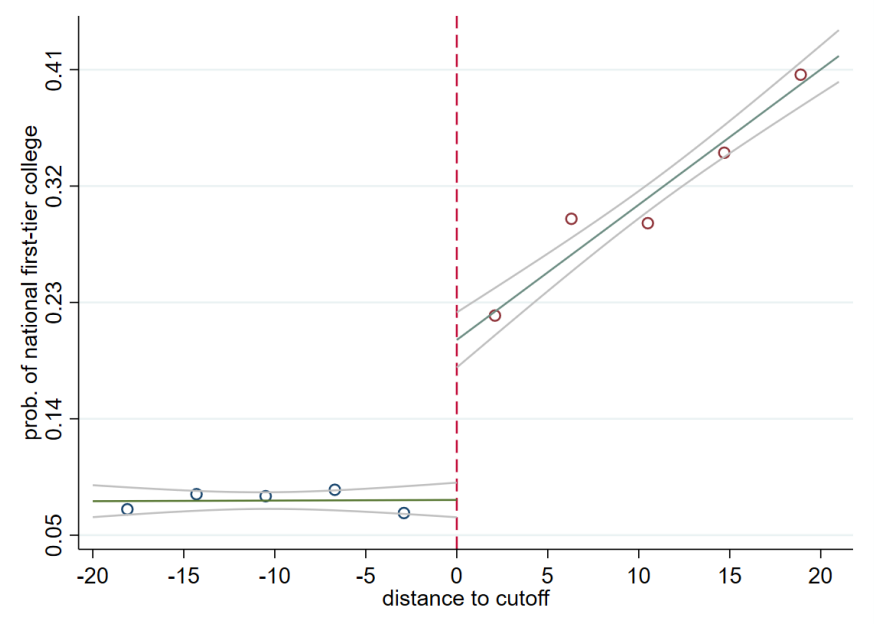

(d) Placebo II: Using next-year cutoffs w. Pr-Ye-Tr FEs

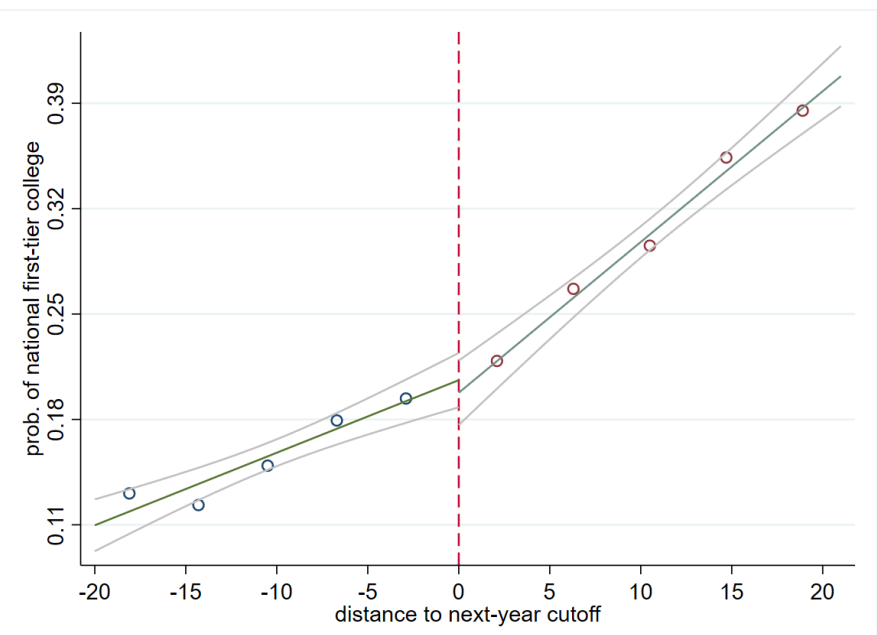

Note. These figures plot the probability of attending an elite (national first-tier) college against distance to the cutoff scores (which vary by province-year-track). Panel (a) is based on raw data; each point corresponds one point in the exam. Panel (b) controls for province-year-track fixed effects and plots the residuals that are averaged into 4-point bins. Panels (c) and (d) plot the probability of admission against the cutoff scores in the previous or following year, controlling for province-year-track fixed effects and using 4-point averaged bins. 
Figure 3: Wages vs. Distance to Elite-tier Cutoff

(a) Wage, with Province-Year-Track FEs

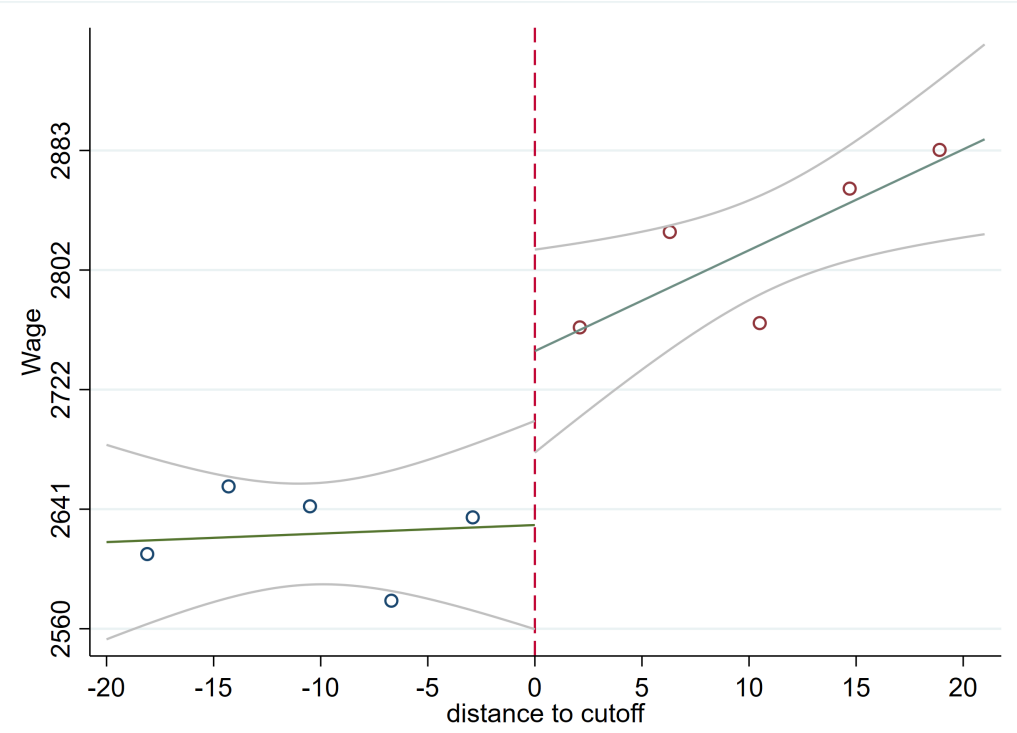

(b) In Wage, with Province-Year-Track FEs

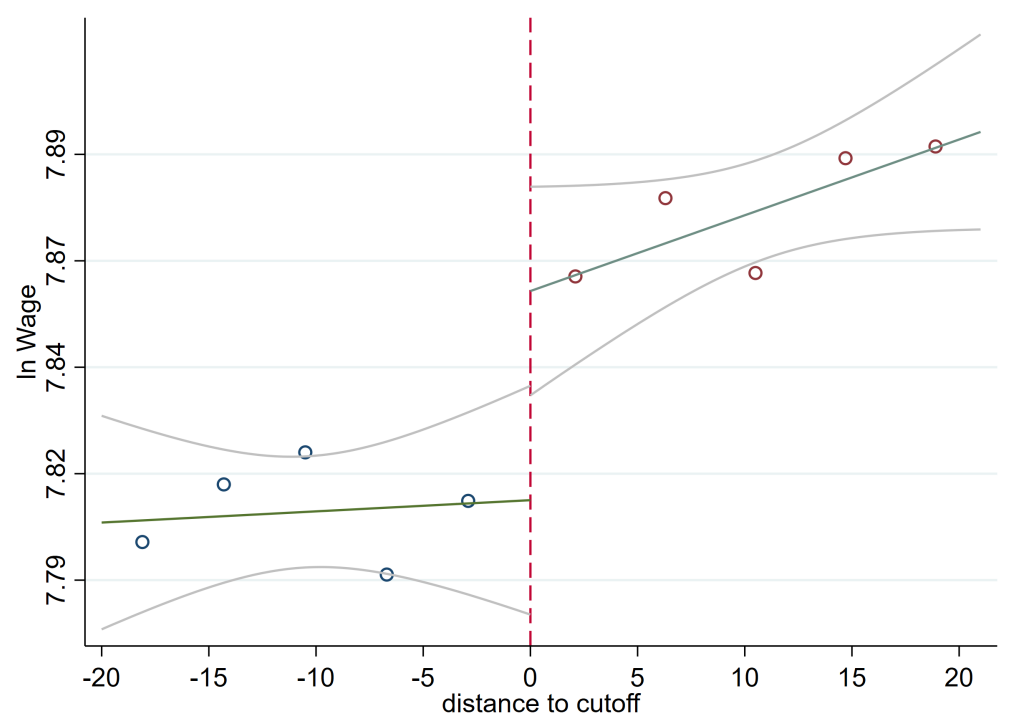

Note. This figure plots wage and log wage by the distance to the cutoff scores (after controlling for province-year-track fixed effects). Each dot indicates the average residual in a 4-point bin. 
Table 1: Summary Statistics

\begin{tabular}{|c|c|c|c|c|c|c|}
\hline & (1) & $(2)$ & (3) & (4) & $(5)$ & $(6)$ \\
\hline Sample & {$[0,20]$} & {$[0,20]$} & {$[-20,0)$} & {$[-20,0)$} & Above cutoff & Below cutoff \\
\hline Variable & Mean & SD & Mean & $\mathrm{SD}$ & Mean & Mean \\
\hline \multicolumn{7}{|l|}{ (a) College outcomes } \\
\hline & \multicolumn{2}{|c|}{$\mathrm{n}=5,698$} & \multicolumn{2}{|c|}{$\mathrm{n}=4,637$} & $\mathrm{n}=18,507$ & $\mathrm{n}=16,227$ \\
\hline \multirow{2}{*}{$\begin{array}{c}\text { Elite colleges (national first tier) } \\
\text { national local first tier }\end{array}$} & 0.34 & 0.47 & 0.05 & 0.21 & 0.54 & 0.05 \\
\hline & 0.63 & 0.48 & 0.21 & 0.41 & 0.76 & 0.12 \\
\hline \multirow{3}{*}{$\begin{array}{l}\text { Major: STEM } \\
\text { Major: Econ-Finance-Law } \\
\text { Major: Humanities }\end{array}$} & 0.68 & 0.47 & 0.62 & 0.49 & 0.65 & 0.54 \\
\hline & 0.22 & 0.41 & 0.27 & 0.44 & 0.19 & 0.31 \\
\hline & 0.10 & 0.30 & 0.10 & 0.30 & 0.14 & 0.13 \\
\hline \multicolumn{7}{|l|}{ (b) Individual characteristics } \\
\hline Male & 0.59 & 0.49 & 0.56 & 0.50 & 0.58 & 0.52 \\
\hline Age & 23.96 & 1.11 & 23.97 & 1.10 & 23.76 & 23.92 \\
\hline Rural Hukou & 0.58 & 0.49 & 0.58 & 0.49 & 0.51 & 0.53 \\
\hline Repeated exam taker & 0.32 & 0.46 & 0.32 & 0.47 & 0.25 & 0.26 \\
\hline Father w. college edu. & 0.09 & 0.29 & 0.08 & 0.27 & 0.14 & 0.08 \\
\hline Mother w. college edu. & 0.06 & 0.24 & 0.05 & 0.22 & 0.09 & 0.05 \\
\hline ln Father's income & 9.88 & 1.13 & 9.91 & 1.08 & 10.00 & 9.98 \\
\hline ln Mother's income & 9.35 & 1.20 & 9.41 & 1.16 & 9.53 & 9.50 \\
\hline ln Household income & 10.42 & 1.13 & 10.48 & 1.09 & 10.55 & 10.55 \\
\hline Father being a Party member & 0.22 & 0.42 & 0.22 & 0.41 & 0.27 & 0.21 \\
\hline Mother being a Party member & 0.08 & 0.27 & 0.08 & 0.27 & 0.10 & 0.08 \\
\hline \multicolumn{7}{|l|}{ (c) Wage outcome } \\
\hline & \multicolumn{2}{|c|}{$\mathrm{n}=2,794$} & \multicolumn{2}{|c|}{$\mathrm{n}=2,286$} & $\mathrm{n}=7,750$ & $\mathrm{n}=7,586$ \\
\hline ln Wage & 7.89 & 0.37 & 7.79 & 0.37 & 7.93 & 7.70 \\
\hline
\end{tabular}

Note. The data come from six rounds of annual surveys on college graduates conducted by the authors. Columns (1)-(4) restrict the sample to students with scores 20 points around the cutoff scores; Columns (5)-(6) do not restrict the sample. The number of observations with wages is smaller than that with scores, as not every student looks for jobs after graduation. 
Table 2: Balance Tests: Scoring Above the Cutoff vs. Individual Characteristics

\begin{tabular}{|c|c|c|c|c|c|c|c|c|c|c|}
\hline & $\begin{array}{c}(1) \\
\text { Male }\end{array}$ & $\begin{array}{l}(2) \\
\text { Age }\end{array}$ & $\begin{array}{c}\text { (3) } \\
\text { Repeated }\end{array}$ & $\begin{array}{c}(4) \\
\text { Rural }\end{array}$ & $\begin{array}{c}(5) \\
\text { Ln(Father } \\
\text { Income })\end{array}$ & $\begin{array}{c}(6) \\
\text { Ln(Mother } \\
\text { Income) }\end{array}$ & $\begin{array}{c}(7) \\
\text { Ln(Family } \\
\text { Income })\end{array}$ & $\begin{array}{c}(8) \\
\text { Parent } \\
\text { College }\end{array}$ & $\begin{array}{c}\text { (9) } \\
\text { Parent } \\
\text { Party Mem. }\end{array}$ & $\begin{array}{c}(10) \\
\text { Predicted } \\
\text { Wage }\end{array}$ \\
\hline \multicolumn{11}{|c|}{ (a) Sample within a 20-point bandwidth } \\
\hline Above cutoff & $\begin{array}{l}-0.007 \\
(0.029)\end{array}$ & $\begin{array}{c}0.001 \\
(0.076)\end{array}$ & $\begin{array}{l}-0.035 \\
(0.033)\end{array}$ & $\begin{array}{c}0.014 \\
(0.026)\end{array}$ & $\begin{array}{c}0.031 \\
(0.067)\end{array}$ & $\begin{array}{c}0.038 \\
(0.083)\end{array}$ & $\begin{array}{c}0.023 \\
(0.060)\end{array}$ & $\begin{array}{l}-0.015 \\
(0.020)\end{array}$ & $\begin{array}{c}-0.004 \\
(0.024)\end{array}$ & $\begin{array}{l}-0.002 \\
(0.007)\end{array}$ \\
\hline \multicolumn{11}{|c|}{ (b) Sample within a 20-point bandwidth and with wage offers } \\
\hline Above cutoff & $\begin{array}{c}-0.007 \\
(0.029)\end{array}$ & $\begin{array}{c}0.001 \\
(0.076)\end{array}$ & $\begin{array}{l}-0.035 \\
(0.033)\end{array}$ & $\begin{array}{c}0.014 \\
(0.026)\end{array}$ & $\begin{array}{c}0.031 \\
(0.067)\end{array}$ & $\begin{array}{c}0.038 \\
(0.083)\end{array}$ & $\begin{array}{c}0.023 \\
(0.060)\end{array}$ & $\begin{array}{l}-0.015 \\
(0.020)\end{array}$ & $\begin{array}{l}-0.004 \\
(0.024)\end{array}$ & $\begin{array}{l}-0.002 \\
(0.007)\end{array}$ \\
\hline Prov-Year-Track FE & $\mathrm{Y}$ & $\mathrm{Y}$ & $\mathrm{Y}$ & $\mathrm{Y}$ & $\mathrm{Y}$ & $\mathrm{Y}$ & $\mathrm{Y}$ & $\mathrm{Y}$ & $\mathrm{Y}$ & $\mathrm{Y}$ \\
\hline
\end{tabular}

Note. This table reports results from balance tests for the sample within the bandwidth and the subsample with wage information. The regressions in both Panels (a) and (b) use the sample within the 20-point bandwidth, and Panel (b) further restrict the sample to observing wage offers. All regressions use the parametric method with quadratic interactions. Standard errors are two-way clustered at the college and province-year-track levels. Significance levels: $* 10 \%, * * 5 \%, * * * 1 \%$. The dependent variable in Column (10) is the wage predicted by other characteristics, i.e., those dependent variables in Columns (1)-(9) 
Table 3: The Effect of Scoring Above Cutoff on the Probability of Elite College Admission

\begin{tabular}{|c|c|c|c|c|c|c|c|c|c|c|}
\hline & (1) & (2) & (3) & (4) & (5) & (6) & (7) & (8) & (9) & (10) \\
\hline Elite College & \multicolumn{5}{|c|}{ National First-Tier College (mean: 0.21) } & \multicolumn{5}{|c|}{ National + Local First-Tier College (mean: 0.44) } \\
\hline Method & Local Linear & Parametric & Parametric & Parametric & Parametric & Local Linear & Parametric & Parametric & Parametric & Parametric \\
\hline Interaction controls & & Linear & Quadratic & Linear & Quadratic & & Linear & Quadratic & Linear & Quadratic \\
\hline Weighted & & & & $\mathrm{Y}$ & $\mathrm{Y}$ & & & & $\mathrm{Y}$ & $\mathrm{Y}$ \\
\hline Prov-Year-Track FE & & Y & Y & Y & $\mathrm{Y}$ & & Y & Y & Y & $\mathrm{Y}$ \\
\hline Above cutoff & $\begin{array}{c}0.165 * * * \\
(0.013)\end{array}$ & $\begin{array}{c}0.155^{* * * *} \\
(0.047)\end{array}$ & $\begin{array}{c}0.159 * * * \\
(0.039)\end{array}$ & $\begin{array}{c}0.182 * * * \\
(0.049)\end{array}$ & $\begin{array}{c}0.184 * * * \\
(0.047)\end{array}$ & $\begin{array}{c}0.142 * * * * \\
(0.020)\end{array}$ & $\begin{array}{c}0.159 * * * \\
(0.054)\end{array}$ & $\begin{array}{c}0.169 * * * \\
(0.042)\end{array}$ & $\begin{array}{c}0.172 * * * \\
(0.048)\end{array}$ & $\begin{array}{c}0.163 * * * \\
(0.042)\end{array}$ \\
\hline Observations & 10,335 & 10,335 & 10,335 & 10,335 & 10,335 & 10,335 & 10,335 & 10,335 & 10,335 & 10,335 \\
\hline R-squared & & 0.344 & 0.344 & 0.438 & 0.438 & & 0.514 & 0.514 & 0.582 & 0.582 \\
\hline
\end{tabular}

Note. This table reports results using the sample within the 20-point bandwidth. The results in Columns (1) and (5) are obtained from local linear methods, and the other results come from parametric methods with linear or quadratic controls while allowing for different slopes around the cutoff. Standard errors for all parametric specifications are two-way clustered at the college and province-year-track levels. Significance levels: $* 10 \%, * * 5 \%, * * * 1 \%$

For weighted regressions, the weight is generated to reflect the population data, based on the population (administrative data) of all college students in 2003. 
Table 4: The Effect of Scoring Above the Cutoff Score on the Major and Class Ranking in College

\begin{tabular}{|c|c|c|c|c|c|c|c|c|c|c|c|c|}
\hline \multirow{6}{*}{$\begin{array}{l}\text { Method } \\
\text { Interaction controls } \\
\text { Weighted } \\
\text { Prov-Year-Track FE }\end{array}$} & \multirow{6}{*}{$\begin{array}{r}(1) \\
\text { Major: } \\
\text { Local Linear }\end{array}$} & \multirow{3}{*}{$\begin{array}{c}\text { (2) } \\
\text { Econ-Financ } \\
\text { Parametric }\end{array}$} & \multirow{2}{*}{ (3) } & \multirow[t]{2}{*}{$(4)$} & \multirow{3}{*}{$\begin{array}{c}\text { (5) } \\
\text { STEM } \\
\text { Parametric }\end{array}$} & \multirow{2}{*}{ (6) } & (7) & $(8)$ & \multirow[t]{2}{*}{ (9) } & \multirow[t]{2}{*}{$(10)$} & \multirow{2}{*}{$\frac{(11)}{\text { Bottom } 20 \%}$} & \multirow[t]{2}{*}{$(12)$} \\
\hline & & & & & & & & Humanities & & & & \\
\hline & & & Parametric & Local Linear & & Parametric & Local Linear & Parametric & Parametric & Local Linear & Parametric & Parametric \\
\hline & & Quadratic & Quadratic & & Quadratic & Quadratic & & Quadratic & Quadratic & & Quadratic & Quadratic \\
\hline & & & $\mathrm{Y}$ & & & $\mathrm{Y}$ & & & $\mathrm{Y}$ & & & $\mathrm{Y}$ \\
\hline & & $\mathrm{Y}$ & $\mathrm{Y}$ & & $\mathrm{Y}$ & $\mathrm{Y}$ & & $\mathrm{Y}$ & $\mathrm{Y}$ & & $\mathrm{Y}$ & $\mathrm{Y}$ \\
\hline Above cutoff & $\begin{array}{c}-0.034 * \\
(0.018)\end{array}$ & $\begin{array}{l}-0.041 \\
(0.032)\end{array}$ & $\begin{array}{l}-0.082^{*} \\
(0.042)\end{array}$ & $\begin{array}{l}-0.008 \\
(0.020)\end{array}$ & $\begin{array}{c}0.025 \\
(0.031)\end{array}$ & $\begin{array}{c}0.021 \\
(0.036)\end{array}$ & $\begin{array}{c}0.040 * * * \\
(0.013)\end{array}$ & $\begin{array}{c}0.017 \\
(0.012)\end{array}$ & $\begin{array}{c}0.057 * * \\
(0.022)\end{array}$ & $\begin{array}{c}0.033 * * * \\
(0.009)\end{array}$ & $\begin{array}{c}0.046 * * * \\
(0.013)\end{array}$ & $\begin{array}{c}0.040 * * \\
(0.019)\end{array}$ \\
\hline Observations & 10,335 & 10,335 & 10,335 & 10,335 & 10,335 & 10,335 & 10,335 & 10,335 & 10,335 & 10,335 & 10,335 & 10,335 \\
\hline R-squared & & 0.239 & 0.316 & & 0.513 & 0.558 & & 0.321 & 0.360 & & 0.052 & 0.065 \\
\hline
\end{tabular}

Note. This table reports results using the sample within the 20-point bandwidth. The results in Columns (1), (4), (7) and (10) are obtained from local linear methods, and the other results are from parametric methods with quadratic controls while allowing for different slopes around the cutoff. Standard errors for all parametric specifications are two-way clustered at the college and province-year-track levels. Significance levels: $* 10 \%, * * 5 \%, * * * 1 \%$.

For weighted regressions, the weight is generated to reflect the population data, based on the population (administrative data) of all college students in 2003. 
Table 5: The Effect of Scoring above the Cutoff Score on First-job Wages and Admissions to Elite Colleges

\begin{tabular}{|c|c|c|c|c|c|}
\hline & (1) & (2) & (3) & (4) & (5) \\
\hline $\begin{array}{l}\text { Method } \\
\text { Interaction controls } \\
\text { Weighted }\end{array}$ & Local Linear & $\begin{array}{l}\text { Parametric } \\
\text { Linear }\end{array}$ & $\begin{array}{l}\text { Parametric } \\
\text { Quadratic }\end{array}$ & $\begin{array}{l}\text { Parametric } \\
\text { Linear } \\
\text { Y }\end{array}$ & $\begin{array}{c}\text { Parametric } \\
\text { Quadratic } \\
\text { Y }\end{array}$ \\
\hline Prov.-Year-Track FE & & Y & Y & Y & Y \\
\hline A. Dependent variable & & & ln Wage & & \\
\hline Above cutoff & $\begin{array}{c}0.053 * * \\
(0.023)\end{array}$ & $\begin{array}{c}0.059 * * * \\
(0.020)\end{array}$ & $\begin{array}{c}0.067 * * \\
(0.026)\end{array}$ & $\begin{array}{c}0.052 * * \\
(0.022)\end{array}$ & $\begin{array}{c}0.092 * * \\
(0.038)\end{array}$ \\
\hline B. Dependent variable & \multicolumn{5}{|c|}{ Elite (National First-Tier) College } \\
\hline Above cutoff & $\begin{array}{c}0.162 * * * \\
(0.018)\end{array}$ & $\begin{array}{c}0.155^{* * *} \\
(0.056)\end{array}$ & $\begin{array}{c}0.147 * * * \\
(0.048)\end{array}$ & $\begin{array}{c}0.185 * * * \\
(0.054)\end{array}$ & $\begin{array}{c}0.147 * * * \\
(0.054)\end{array}$ \\
\hline C. Dependent variable & \multicolumn{5}{|c|}{ ln Wage } \\
\hline Elite college (instrumented) & $\begin{array}{c}0.328 * * * \\
(0.145)\end{array}$ & $\begin{array}{c}0.380 * * \\
(0.176)\end{array}$ & $\begin{array}{c}0.456 * * \\
(0.228)\end{array}$ & $\begin{array}{c}0.283 * * * * \\
(0.154)\end{array}$ & $\begin{array}{c}0.624 \\
(0.380)\end{array}$ \\
\hline Observations & 5,080 & 5,080 & 5,080 & 5,080 & 5,080 \\
\hline
\end{tabular}

Note. This table reports results using the sample within the 20-point bandwidth and with information on wages. The results in Column (1) are obtained from the local linear method, and the other results are from parametric methods with linear or quadratic controls while allowing for different slopes around the cutoff. Standard errors for all parametric specifications are two-way clustered at the college and province-year-track levels. Significance levels: *10\%, **5\%, ***1\%.

For weighted regressions, the weight is generated to reflect the population data, based on the population (administrative data) of all college students in 2003. 
Table 6: The Effect of First-job Wages on Future-job Wages

Dependent Variable: Wage Rank (standardized)

\begin{tabular}{|c|c|c|c|c|c|c|}
\hline \multirow[t]{2}{*}{ Year after graduation } & \multicolumn{3}{|c|}{$1-5$} & \multicolumn{3}{|c|}{$6-10$} \\
\hline & (1) & $(2)$ & (3) & (4) & $(5)$ & $(6)$ \\
\hline First-job wage rank (sd) & $\begin{array}{c}0.731 * * * \\
(0.002)\end{array}$ & $\begin{array}{c}0.695^{* * *} * \\
(0.003)\end{array}$ & $\begin{array}{c}0.682 * * * \\
(0.003)\end{array}$ & $\begin{array}{c}0.681 * * * \\
(0.006)\end{array}$ & $\begin{array}{c}0.673 * * * \\
(0.007)\end{array}$ & $\begin{array}{c}0.651 * * * \\
(0.009)\end{array}$ \\
\hline First-job wage ranks $(\mathrm{sd}) *$ Elite college & & & $\begin{array}{c}0.034 * * * \\
(0.005)\end{array}$ & & & $\begin{array}{c}0.045^{* * * *} \\
(0.013)\end{array}$ \\
\hline Age, Sex & & $\mathrm{Y}$ & $\mathrm{Y}$ & & Y & $\mathrm{Y}$ \\
\hline College FEs & & Y & Y & & Y & Y \\
\hline Age*Elite college, Sex*Elite college & & & $\mathrm{Y}$ & & & Y \\
\hline Observations & 146,900 & 146,900 & 146,900 & 28,057 & 28,057 & 28,057 \\
\hline R-squared & 0.623 & 0.656 & 0.657 & 0.434 & 0.524 & 0.525 \\
\hline
\end{tabular}

Note. The data are drawn from a major online job search platform. Wages are reported in categories: 1 for below 1,000 RMB, 2 for 1,000-2,000 RMB, 3 for 2,001-4,000 RMB, 4 for 4,001-6,000 RMB, and 5 for 6,001 RMB and above. All wage rank variables are standardized. Standard errors are clustered at the college level. Significance levels: * $10 \%, * * 5 \%, * * * 1 \%$. 
Table 7: The Effect of Scoring Above Cutoff on Time Use and Achievement in College

\begin{tabular}{|c|c|c|c|c|c|c|c|c|c|c|c|c|}
\hline \multirow{3}{*}{$\begin{array}{l}\text { Method } \\
\text { Weighted }\end{array}$} & (1) & (2) & (3) & (4) & (5) & (6) & (7) & (8) & (9) & $(10)$ & $(11)$ & (12) \\
\hline & \multicolumn{12}{|c|}{ Parametric, Quadratic interaction controls } \\
\hline & & $\mathrm{Y}$ & & $\mathrm{Y}$ & & $\mathrm{Y}$ & & $\mathrm{Y}$ & & $\mathrm{Y}$ & & $\mathrm{Y}$ \\
\hline \multirow[t]{2}{*}{ Prov-Year-Track FE } & $\mathrm{Y}$ & $\mathrm{Y}$ & $\mathrm{Y}$ & $\mathrm{Y}$ & $\mathrm{Y}$ & $\mathrm{Y}$ & $\mathrm{Y}$ & $\mathrm{Y}$ & $\mathrm{Y}$ & $\mathrm{Y}$ & $\mathrm{Y}$ & $\mathrm{Y}$ \\
\hline & \multicolumn{12}{|c|}{ A. Time Use in College } \\
\hline Dependent var. & \multicolumn{2}{|c|}{ Class } & \multicolumn{2}{|c|}{ Study oneself } & \multicolumn{2}{|c|}{ Work } & \multicolumn{2}{|c|}{ Sport } & \multicolumn{2}{|c|}{ Entertainment } & \multicolumn{2}{|c|}{ Internet } \\
\hline Mean & \multicolumn{2}{|c|}{24.8} & \multicolumn{2}{|c|}{13.0} & \multicolumn{2}{|c|}{6.6} & \multicolumn{2}{|c|}{5.7} & \multicolumn{2}{|c|}{8.6} & \multicolumn{2}{|c|}{13.1} \\
\hline Above cutoff & $\begin{array}{l}-0.428 \\
(1.043)\end{array}$ & $\begin{array}{c}0.393 \\
(1.549)\end{array}$ & $\begin{array}{c}0.873 \\
(0.861)\end{array}$ & $\begin{array}{c}1.668 \\
(1.428)\end{array}$ & $\begin{array}{l}-0.041 \\
(0.726)\end{array}$ & $\begin{array}{c}0.151 \\
(0.850)\end{array}$ & $\begin{array}{c}0.247 \\
(0.498)\end{array}$ & $\begin{array}{c}-0.202 \\
(0.499)\end{array}$ & $\begin{array}{c}0.159 \\
(0.652)\end{array}$ & $\begin{array}{c}0.343 \\
(0.907)\end{array}$ & $\begin{array}{l}-0.482 \\
(0.794)\end{array}$ & $\begin{array}{c}0.113 \\
(1.131)\end{array}$ \\
\hline \multirow{2}{*}{ Observations } & 5,080 & 5,080 & 5,080 & 5,080 & 5,080 & 5,080 & 5,080 & 5,080 & 5,080 & 5,080 & 5,080 & 5,080 \\
\hline & \multirow{3}{*}{\multicolumn{2}{|c|}{$\begin{array}{c}\text { CET4 dummy } \\
0.88\end{array}$}} & \multirow{3}{*}{\multicolumn{2}{|c|}{$\begin{array}{c}\text { CET4 score } \\
460\end{array}$}} & \multicolumn{4}{|c|}{ B. Achievement and Certificates } & \multirow{3}{*}{\multicolumn{2}{|c|}{$\begin{array}{c}\text { Vocational } \\
0.19\end{array}$}} & & \\
\hline Dependent var. & & & & & Com & puter & CPA & BAR & & & \multicolumn{2}{|c|}{ Driving } \\
\hline Mean & & & & & 0 . & & & & & & & 31 \\
\hline Above cutoff & $\begin{array}{l}-0.014 \\
(0.033)\end{array}$ & $\begin{array}{l}-0.011 \\
(0.049)\end{array}$ & $\begin{array}{l}-0.080 \\
(3.555)\end{array}$ & $\begin{array}{l}-0.365 \\
(6.371)\end{array}$ & $\begin{array}{c}0.025 \\
(0.038)\end{array}$ & $\begin{array}{c}0.009 \\
(0.047)\end{array}$ & $\begin{array}{c}-0.077 * * \\
(0.036)\end{array}$ & $\begin{array}{c}-0.084 * * \\
(0.041)\end{array}$ & $\begin{array}{l}-0.005 \\
(0.032)\end{array}$ & $\begin{array}{l}-0.059 \\
(0.050)\end{array}$ & $\begin{array}{l}-0.011 \\
(0.033)\end{array}$ & $\begin{array}{l}-0.009 \\
(0.070)\end{array}$ \\
\hline Observations & 5,080 & 5,080 & 5,080 & 5,080 & 5,080 & 5,080 & 5,080 & 5,080 & 5,080 & 5,080 & 5,080 & 5,080 \\
\hline
\end{tabular}

Note. This table reports results using the sample within the 20-point bandwidth and with information on wages. The results are obtained from parametric methods with quadratic controls while allowing for different slopes around the cutoff. Standard errors are two-way clustered at the college and province-year-track levels. Significance levels: $* 10 \%$, $* * 5 \%$, $* * * 1 \%$.

For weighted regressions, the weight is generated to reflect the population data, based on the population (administrative data) of all college students in 2003. 
Table 8: The Effect of Scoring Above the Cutoff on Characteristics of College Peers

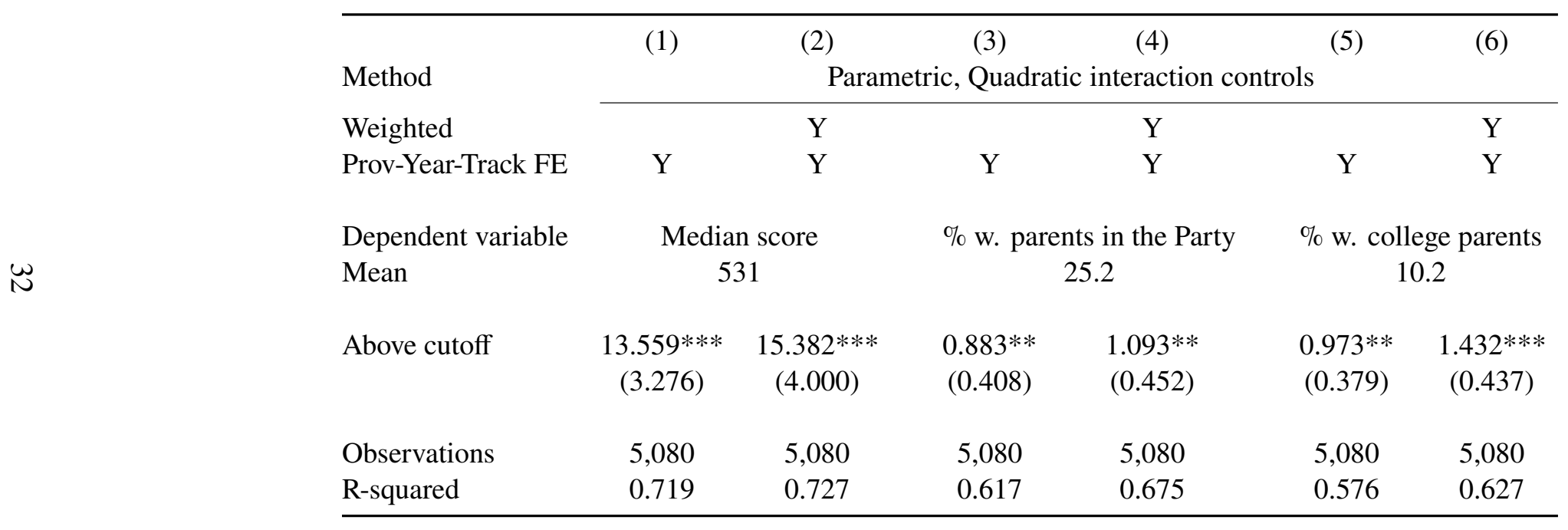

Note. This table reports results using the sample within the 20-point bandwidth and with information on wages. The results are obtained from parametric methods with quadratic controls while allowing for different slopes around the cutoff. Standard errors are two-way clustered at the college and province-year-track levels. Significance levels: $* 10 \%$, $* * 5 \%$, $* * * 1 \%$.

For weighted regressions, the weight is generated to reflect the population data, based on the population (administrative data) of all college students in 2003. 


\section{Online Appendix}

\section{Table of Contents}

A Background, Survey and Data: More Results

A.1 Exam and College Admission: Timing \& Online Search . . . . . . . . . . . . A-2

A.2 Elite vs. Non-Elite Colleges in Our Surveys . . . . . . . . . . . . . . . . . A-3

A.3 Roll-out of Surveys 2010-15 . . . . . . . . . . . . . . . . A-3

A.4 Spatial Distribution of Colleges and Students in Our Surveys . . . . . . . . . . . A-4

A.5 Adjusting Weights Using Administrative Data . . . . . . . . . . . . . A-5

A.6 Score Reporting by Personal Characteristics . . . . . . . . . . . . . . . A-5

B Score above Cutoff vs. Elite College Access: More Results A-6

B.1 Balance Tests: More Results . . . . . . . . . . . . . . . . . . A-6

B.2 Results from Administrative Data . . . . . . . . . . . . . . . . . . . A-9

B.3 More Results on the Local First-tier . . . . . . . . . . . . . . . . A-9

C Score above Cutoff vs. Wages: More Results A-11

C.1 Post-Graduation Plans and Job Search Behaviors . . . . . . . . . . . . . A-11

C.2 Variation in the Wage Premium . . . . . . . . . . . A-11

C.3 Bounding Exercises $\ldots \ldots \ldots \ldots \ldots \ldots \ldots$. . . . . . . . . . . . . .

C.4 Excluding Data in 2014 and $2015 \ldots \ldots \ldots \ldots \ldots \ldots$. . . . . . . . . . . . . . . . . . 


\section{A Background, Survey and Data: More Results}

\section{A.1 Exam and College Admission: Timing \& Online Search}

Using 2015 as an example, we describe the timing of the exam, college application and college admission in Table A.1.

Table A.1: Timeline of College Admission in 2015

\begin{tabular}{|c|c|c|}
\hline Exam Dates & June 6-9, 2015 & $\begin{array}{l}\text { Notes } \\
\text { the same dates for every province }\end{array}$ \\
\hline Score and Cutoff Announced & June 22-25, 2015 & can vary one or two days by province \\
\hline Application Dates & June 25-28, 2015 & can vary one or two days by province \\
\hline \multirow[t]{2}{*}{ Admission Dates } & July 18-August 1, 2015 & can vary a few days by province \\
\hline & & One can be accepted by at most one college. \\
\hline
\end{tabular}

As shown in Figure A.1, the search of "the first-tier cutoff" surges at Baidu.com (the primary search engine in China), around the time students learn their scores. It also confirms that students do not know the cutoff scores at the time of the exam.

Figure A.1: Search for "the First-tier Cutoff" via Baidu

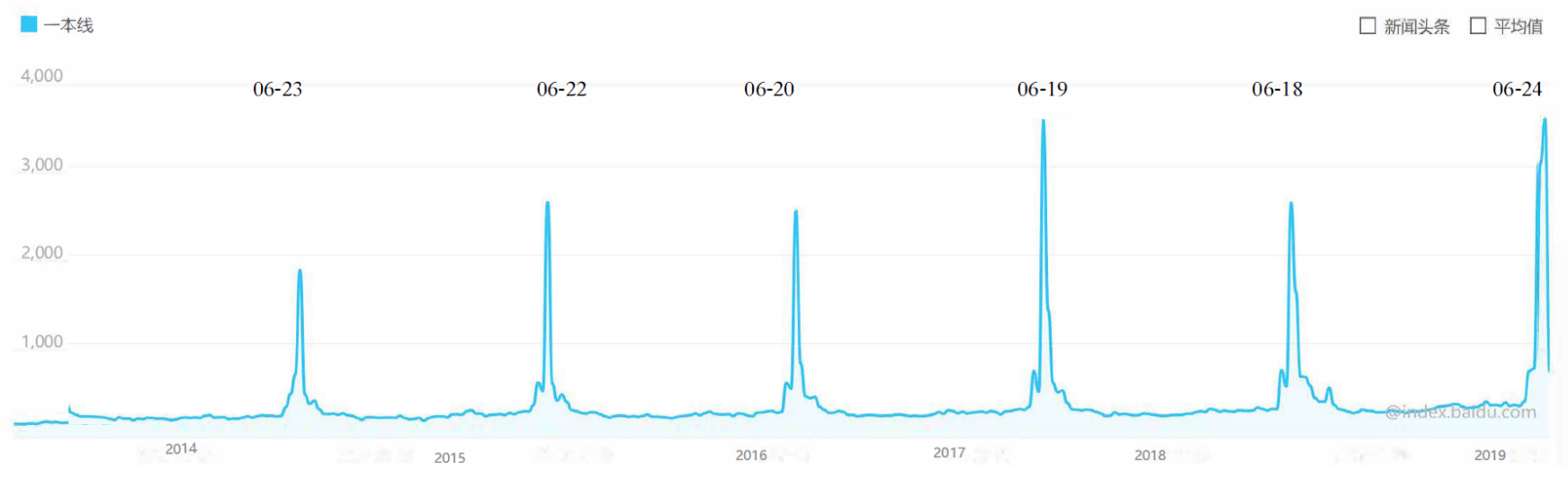

source. index.baidu.com. 


\section{A.2 Elite vs. Non-Elite Colleges in Our Surveys}

Table A.2 reports comparisons between elite (i.e. national first-tier) and non-elite colleges in our surveys.

Table A.2: Elite vs. Non-Elite Colleges in Our Survey

\begin{tabular}{lccc}
\hline & $(1)$ & $(2)$ & $(3)$ \\
& 26 Elite (national first-tier colleges & 64 non-elite colleges & Difference \\
\cline { 2 - 4 } & & & \\
\# All students (Median) & 19,380 & 18,655 & 724 \\
\# Graduate students (Median) & $(9,712)$ & $(14,632)$ & $(3,270)$ \\
& 4,733 & 4,598 & 135 \\
\# Foreign students (Median) & $(2,418)$ & $(3,392)$ & $(769)$ \\
& 590 & 182 & $408^{* * *}$ \\
Median Tuition (RMB a year) & $(653)$ & $(344)$ & $(114)$ \\
& 5,020 & 6,196 & $-1,176^{*}$ \\
Share of Students from Other Provinces & $(443)$ & $(3,444)$ & $(680)$ \\
& 0.64 & 0.31 & $0.33^{* * *}$ \\
Median Exam Score & $(0.24)$ & $(0.24)$ & $(0.05)$ \\
& 590 & 491 & $98^{* * *}$ \\
\end{tabular}

Note. Columns (1)-(2) present the mean and standard deviation for each variable by college status. Column (3) test the differences, where standardized error are clustered at the college level.

\section{A.3 Roll-out of Surveys 2010-15}

We report the number of colleges and the number of students in survey year in Table A.3.

Table A.3: Roll-out of Surveys 2010-15

\begin{tabular}{lccc}
\hline & \#colleges & \#students per college & Total \#students \\
\cline { 2 - 4 } 2010 & 19 & 319 & 6,060 \\
2011 & 50 & 164 & 8,176 \\
2012 & 50 & 173 & 8,650 \\
2013 & 65 & 164 & 10,679 \\
2014 & 17 & 212 & 3,607 \\
2015 & 13 & 288 & 3,744 \\
Total & 90 & & 40,916 \\
\hline
\end{tabular}

The selection of schools, however, is unlikely to affect our strategy exploring individual-level information on exam performance. The participation of colleges is voluntary in 2014 and 2015. We 
use all the data in our baseline analysis and show that our findings are robust to excluding the data in 2014 and 2015 (presented in Online Appendix C.4).

\section{A.4 Spatial Distribution of Colleges and Students in Our Surveys}

Our surveys cover colleges and students from localities across the country. Figure A.4(a) below plots the distribution of the 90 Colleges in our survey by provinces. Their students come from all provinces across China, as shown in Figure A.4(b).

Figure A.4: The Distribution of Colleges and Students in Our Survey

(a) Distribution of the 90 Colleges

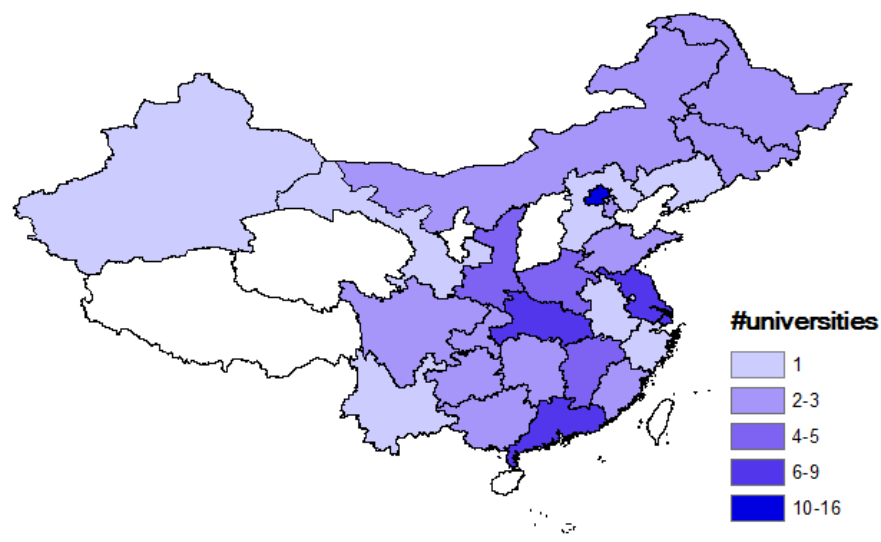

(b) Number of Students by Province of Exam

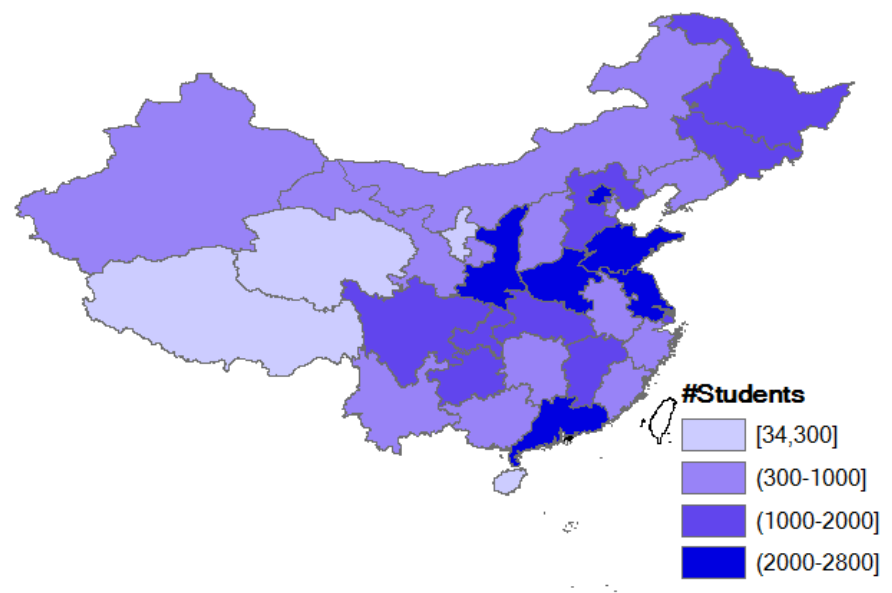




\section{A.5 Adjusting Weights Using Administrative Data}

We employ administrative data on the exam and college admission in 2003 to weight our survey sample. As shown in Figure A.5, after weighting, the probabilities of entering our surveyed colleges are similar around the cutoff.

Figure A.5: Probabilities of Entering Our Surveyed Colleges by Scores

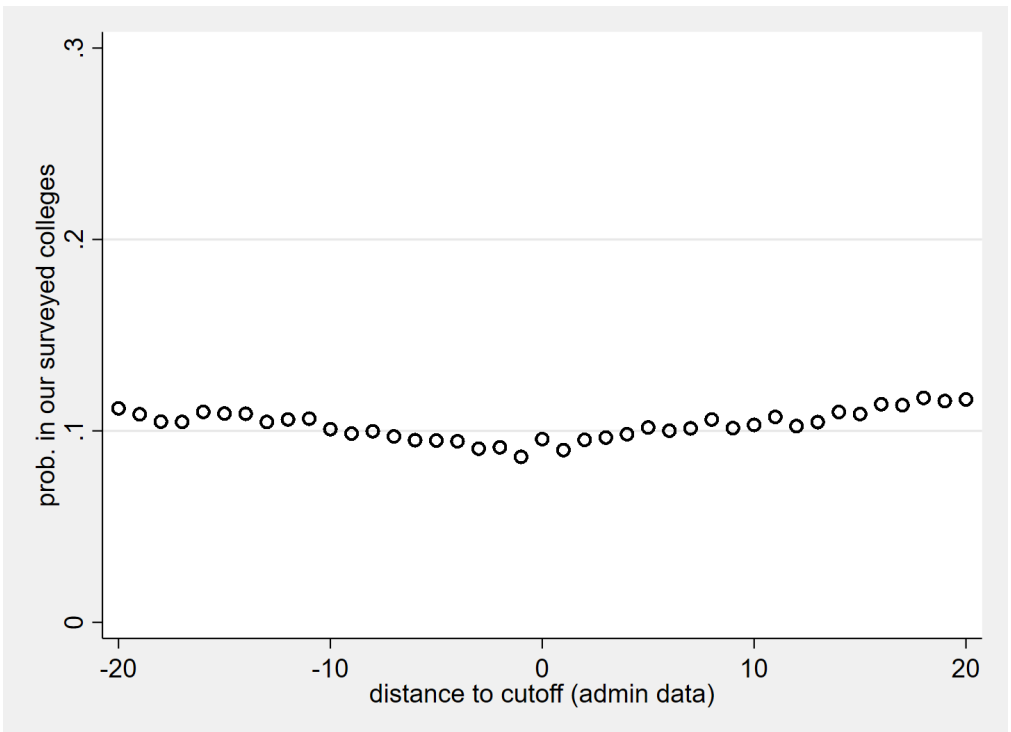

Note. The data on scores refer to those in the administrative data in 2003. The $\mathrm{y}$-axis refers to the probability for a student of Point $\mathrm{X}$ in the administrative data to be enrolled in a college covered by our survey.

\section{A.6 Score Reporting by Personal Characteristics}

Around $15 \%$ of all students in our surveys did not report their exam scores. Below, we show this missing probability correlates with personal characteristics. As shown, the missing probability is not correlated with gender, age, rural status, or family income. Repeated exam takers have a six-percentage-points lower missing rate, and those whose parents hold college degrees have a two-percentage-points higher missing rate. We show that our sample around the cutoff is comparable in all of these personal characteristics. 
Figure A.6: Missing Score vs. Personal Characteristics

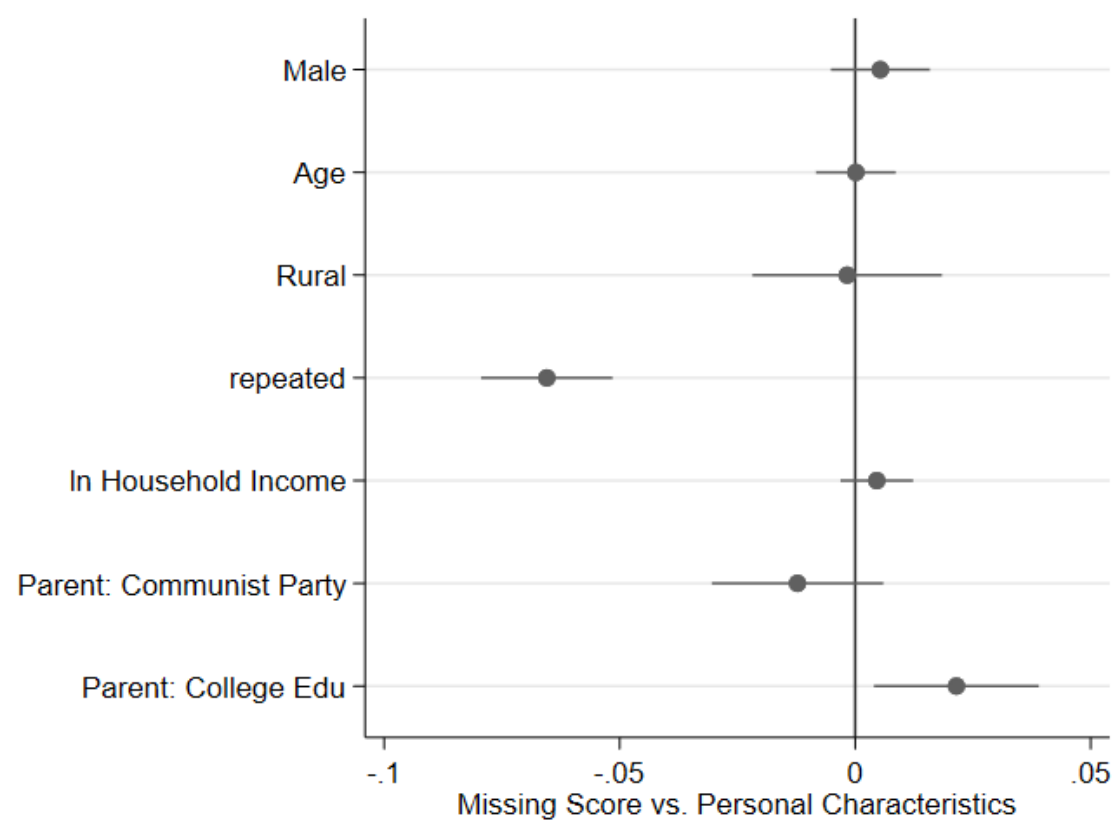

Note. These coefficients and $95 \%$ confidence intervals are obtained from separate regressions where the dependent variable is missing score and the independent variable is each characteristic.

\section{B Score above Cutoff vs. Elite College Access: More Results}

\section{B.1 Balance Tests: More Results}

We visualize the balance tests to show that there is no similar discontinuity in many individual characteristics around the cutoff. Province-year-track fixed effects are controlled for in these figures (next page). Each dot indicates the average residual in a 4-point bin. Their patterns confirm the regression results reported in Table 2(a). 
Figure B.1: Balance Tests of Individual and Family Characteristics

(a) Male

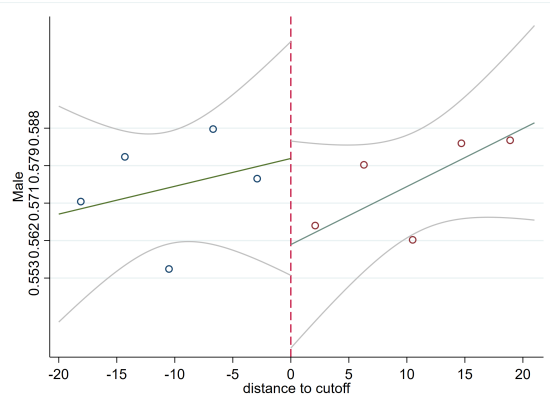

(d) Rural

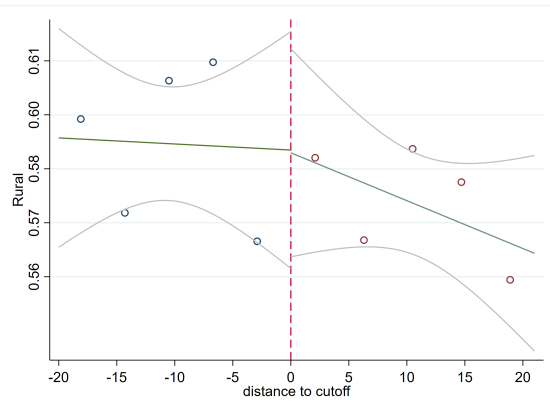

(g) In Family Income

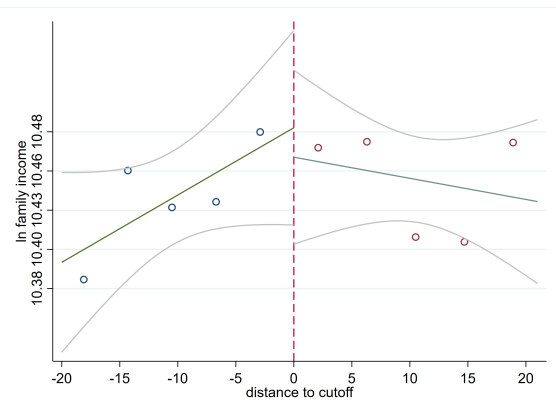

(b) Age

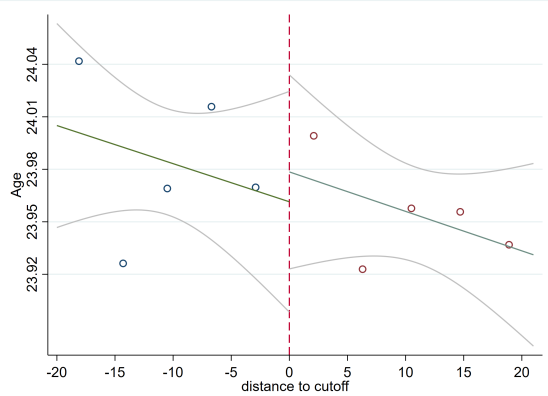

(e) In Father's Income

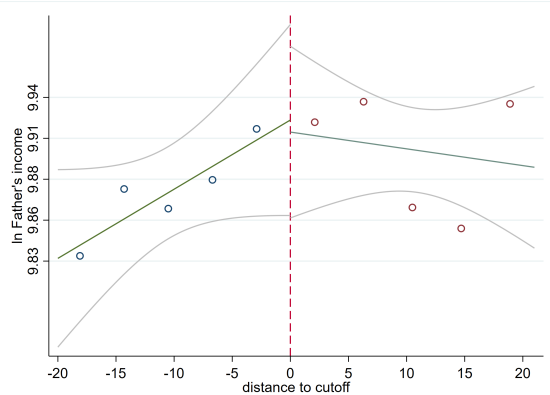

(h) Parent w. College Edu.

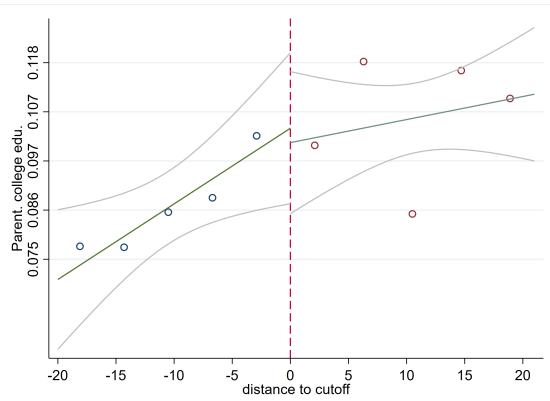

(c) Repeated Exam Takers

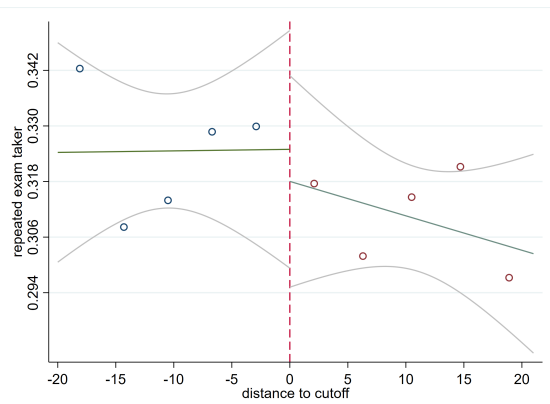

(f) ln Mother's Income

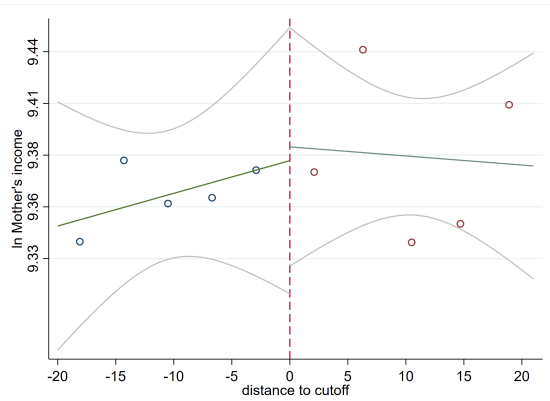

(i) Parent being a Party mem.

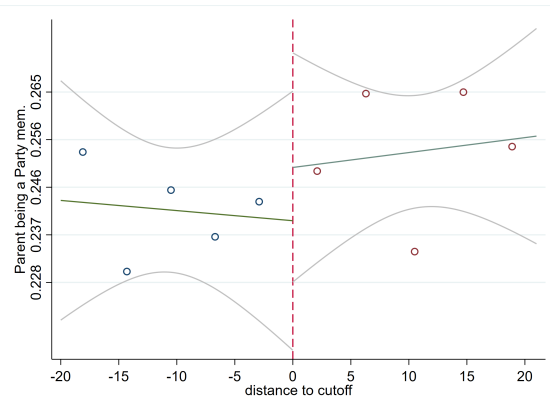

Note. These results are obtained after controlling for province-year-track fixed effects.

We further present the balance tests results when using local linear methods and weighted regressions in Table B.1, which deliver similar patterns. 
Table B.1: A. Balance Tests from Local Linear Estimations

\begin{tabular}{|c|c|c|c|c|c|c|c|c|c|c|}
\hline & $\begin{array}{c}(1) \\
\text { Male }\end{array}$ & $\begin{array}{l}(2) \\
\text { Age }\end{array}$ & $\begin{array}{c}\text { (3) } \\
\text { Repeated }\end{array}$ & $\begin{array}{c}(4) \\
\text { Rural }\end{array}$ & $\begin{array}{c}(5) \\
\text { Ln(Father } \\
\text { Income })\end{array}$ & $\begin{array}{c}(6) \\
\text { Ln(Mother } \\
\text { Income) }\end{array}$ & $\begin{array}{c}(7) \\
\text { Ln(Family } \\
\text { Income })\end{array}$ & $\begin{array}{c}(8) \\
\text { Parent } \\
\text { College }\end{array}$ & $\begin{array}{c}(9) \\
\text { Parent } \\
\text { Party Mem. }\end{array}$ & $\begin{array}{c}(10) \\
\text { Predicted } \\
\text { Wage }\end{array}$ \\
\hline \multicolumn{11}{|c|}{ (a) Sample within a 20-point bandwidth } \\
\hline Above cutoff & $\begin{array}{c}-0.020 \\
(0.021)\end{array}$ & $\begin{array}{c}0.062 \\
(0.051)\end{array}$ & $\begin{array}{l}-0.020 \\
(0.020)\end{array}$ & $\begin{array}{c}0.003 \\
(0.021)\end{array}$ & $\begin{array}{l}-0.025 \\
(0.051)\end{array}$ & $\begin{array}{l}-0.021 \\
(0.058)\end{array}$ & $\begin{array}{l}-0.040 \\
(0.050)\end{array}$ & $\begin{array}{c}-0.011 \\
(0.013)\end{array}$ & $\begin{array}{l}-0.005 \\
(0.019)\end{array}$ & $\begin{array}{l}-0.006 \\
(0.005)\end{array}$ \\
\hline \multicolumn{11}{|c|}{ (b) Sample with a 20-point bandwidth and with wage offers } \\
\hline Above cutoff & $\begin{array}{l}-0.020 \\
(0.021)\end{array}$ & $\begin{array}{c}0.062 \\
(0.051)\end{array}$ & $\begin{array}{l}-0.020 \\
(0.020)\end{array}$ & $\begin{array}{c}0.003 \\
(0.021)\end{array}$ & $\begin{array}{l}-0.025 \\
(0.051)\end{array}$ & $\begin{array}{l}-0.021 \\
(0.058)\end{array}$ & $\begin{array}{l}-0.040 \\
(0.050)\end{array}$ & $\begin{array}{c}-0.011 \\
(0.013)\end{array}$ & $\begin{array}{l}-0.005 \\
(0.019)\end{array}$ & $\begin{array}{l}-0.006 \\
(0.005)\end{array}$ \\
\hline
\end{tabular}

B. Balance Tests from Weighted Estimations Method: Parametric, Quadratic Interaction Controls

\begin{tabular}{|c|c|c|c|c|c|c|c|c|c|c|}
\hline \multirow{4}{*}{$\begin{array}{l}\text { Prov-Year-Track FE } \\
\text { weighted }\end{array}$} & (1) & $(2)$ & (3) & (4) & $(5)$ & (6) & (7) & $(8)$ & (9) & $(10)$ \\
\hline & Y & Y & Y & Y & Y & $\mathrm{Y}$ & $\mathrm{Y}$ & $\mathrm{Y}$ & Y & $\mathrm{Y}$ \\
\hline & $\mathrm{Y}$ & Y & $\mathrm{Y}$ & $\mathrm{Y}$ & Y & Y & Y & Y & Y & Y \\
\hline & Male & Age & Repeated & Rural & $\begin{array}{l}\text { Ln(Father } \\
\text { Income) }\end{array}$ & $\begin{array}{l}\text { Ln(Mother } \\
\text { Income) }\end{array}$ & $\begin{array}{l}\text { Ln(Family } \\
\text { Income) }\end{array}$ & $\begin{array}{l}\text { Parent } \\
\text { College }\end{array}$ & $\begin{array}{c}\text { Parent } \\
\text { Party Mem. }\end{array}$ & $\begin{array}{l}\text { Predicted } \\
\text { Wage }\end{array}$ \\
\hline \multicolumn{11}{|c|}{ (a) Ssample within a 20-point bandwidth } \\
\hline Above cutoff & $\begin{array}{c}0.006 \\
(0.038)\end{array}$ & $\begin{array}{c}0.136 \\
(0.162)\end{array}$ & $\begin{array}{l}-0.062 \\
(0.041)\end{array}$ & $\begin{array}{l}-0.017 \\
(0.039)\end{array}$ & $\begin{array}{c}0.011 \\
(0.068)\end{array}$ & $\begin{array}{c}0.081 \\
(0.094)\end{array}$ & $\begin{array}{c}0.008 \\
(0.075)\end{array}$ & $\begin{array}{c}-0.034 \\
(0.034)\end{array}$ & $\begin{array}{l}-0.007 \\
(0.035)\end{array}$ & $\begin{array}{l}-0.002 \\
(0.006)\end{array}$ \\
\hline \multicolumn{11}{|c|}{ (b) Sample with a 20-point bandwidth and with wage offers } \\
\hline Above cutoff & $\begin{array}{l}-0.050 \\
(0.047)\end{array}$ & $\begin{array}{l}-0.164 \\
(0.090)\end{array}$ & $\begin{array}{l}-0.037 \\
(0.056)\end{array}$ & $\begin{array}{l}-0.043 \\
(0.046)\end{array}$ & $\begin{array}{c}0.136 \\
(0.101)\end{array}$ & $\begin{array}{c}0.188 \\
(0.135)\end{array}$ & $\begin{array}{c}0.061 \\
(0.083)\end{array}$ & $\begin{array}{l}-0.037 \\
(0.025)\end{array}$ & $\begin{array}{l}-0.021 \\
(0.049)\end{array}$ & $\begin{array}{c}0.002 \\
(0.009)\end{array}$ \\
\hline
\end{tabular}

Note. These two tables report more results from balance tests for the sample within the bandwidth and the subsample with wage information, using local linear methods in A and weighted methods in B. 


\section{B.2 Results from Administrative Data}

Using administrative data in 2003, we find that scoring above the cutoff raises the probability of attending an elite college by 0.22 , as shown in Table B.2. This estimate is higher than our baseline estimates but still far from 1, consistent with our discussion in the background.

Table B.2: Results from Administrative Data

\begin{tabular}{|c|c|c|c|}
\hline & (1) & (2) & (3) \\
\hline Method & Local Linear & \multicolumn{2}{|c|}{ Parametric } \\
\hline Interaction controls & & Linear & Quadratic \\
\hline Prov-Year-Track FE & & $\mathrm{Y}$ & $\mathrm{Y}$ \\
\hline Above cutoff & $\begin{array}{c}0.236 * * * \\
(0.005)\end{array}$ & $\begin{array}{c}0.231 * * * \\
(0.005)\end{array}$ & $\begin{array}{c}0.221 * * * \\
(0.008)\end{array}$ \\
\hline Observations & 106,765 & 106,765 & 106,765 \\
\hline R-squared & & 0.246 & 0.246 \\
\hline
\end{tabular}

Note. Standard errors for all parametric specifications are two-way clustered at the college and province-year-track levels. Significance levels: $* 10 \%$, $* * 5 \%, * * * 1 \%$.

\section{B.3 More Results on the Local First-tier}

Is it possible that students select into the local first-tier colleges around the cutoff? To examine this issue, we conduct three additional checks, all of which suggest that this concern is not critical.

First, we check the change in local first-tier enrollment alone across the threshold and find the change is small and insignificant, as reported in Columns (1)-(2) of Table B.3.

Second, we further conduct two heterogeneity checks by rural/urban status and household income. Again, we do not find one specific group systematically more likely to switch to local first tier around the cutoff, as shown in Columns (3)-(6).

Third, differentiating provinces with and without local first-tier colleges is another way to examine this issue. The complexity in our setting, however, is that different provinces are assigned very uneven quotas (which is an interesting issue but beyond the scope of this paper). To make these provinces comparable, we report the RD coefficient relative to the mean of each group. As shown in Columns (7)-(9), the average effect is $76.2 \%$ of the mean, and the estimates for the two subgroups of provinces are not dramatically different ( $68.7 \%$ and $77.7 \%$ respectively). 
Table B.3: Checks on the Local First-tier Colleges

\begin{tabular}{|c|c|c|c|c|c|c|c|c|c|}
\hline & (1) & (2) & (3) & (4) & $(5)$ & (6) & (7) & (8) & (9) \\
\hline Dependent var. & \multicolumn{6}{|c|}{ Local first tier } & \multicolumn{3}{|c|}{ National \& local first tier / mean } \\
\hline Sample & All & All & Rural & Urban & $\begin{array}{l}\text { HH income } \\
\text { above median }\end{array}$ & $\begin{array}{l}\text { HH income } \\
\text { below median }\end{array}$ & All & $\begin{array}{l}\text { Provinces w. } \\
\text { local first-tier }\end{array}$ & Other provinces \\
\hline Method & Parametric & Parametric & Parametric & Parametric & Parametric & Parametric & Parametric & Parametric & Parametric \\
\hline Controls & Linear & Quadratic & Quadratic & Quadratic & Quadratic & Quadratic & Quadratic & Quadratic & Quadratic \\
\hline Prov-Year-Track FE & $\mathrm{Y}$ & $\mathrm{Y}$ & $\mathrm{Y}$ & $\mathrm{Y}$ & $\mathrm{Y}$ & $\mathrm{Y}$ & $\mathrm{Y}$ & $\mathrm{Y}$ & $\mathrm{Y}$ \\
\hline Above Cutoff & $\begin{array}{c}0.004 \\
(0.039)\end{array}$ & $\begin{array}{c}0.010 \\
(0.035)\end{array}$ & $\begin{array}{c}0.032 \\
(0.042)\end{array}$ & $\begin{array}{l}-0.003 \\
(0.039)\end{array}$ & $\begin{array}{l}-0.017 \\
(0.035)\end{array}$ & $\begin{array}{c}0.037 \\
(0.043)\end{array}$ & $\begin{array}{c}0.762 * * * \\
(0.189)\end{array}$ & $\begin{array}{c}0.687 * * * \\
(0.236)\end{array}$ & $\begin{array}{c}0.777 * * * \\
(0.232)\end{array}$ \\
\hline Observations & 10,335 & 10,335 & 6,025 & 4,310 & 4,574 & 5,761 & 10,335 & 5,737 & 4,598 \\
\hline R-squared & 0.408 & 0.408 & 0.467 & 0.395 & 0.470 & 0.393 & 0.344 & 0.293 & 0.566 \\
\hline
\end{tabular}

Note. This table reports results using the sample within the 20-point bandwidth. Standard errors for all parametric specifications are two-way clustered at the college and province-year-track levels. Significance levels: $* 10 \%, * * 5 \%, * * * 1 \%$. 


\section{Score above Cutoff vs. Wages: More Results}

\section{C.1 Post-Graduation Plans and Job Search Behaviors}

We asked about plans post college graduation and job search behavior. These results are presented in Table C.1 There is no big difference for doing graduate studies in China or abroad immediately after graduation for those around the cutoff. Those above the cutoff, however, are more likely report "wait and see". Related to this result, those above the cutoff are weakly less likely to search for a job, but the coefficient of the above-cutoff dummy is not significant.

Table C.1: Plans and Job Search Behaviors

\begin{tabular}{|c|c|c|c|c|c|c|c|c|}
\hline & (1) & (2) & (3) & (4) & $(5)$ & (6) & (7) & (8) \\
\hline Method & \multicolumn{8}{|c|}{ Parametric, Quadratic interaction controls } \\
\hline Weighted & & $\mathrm{Y}$ & & $\mathrm{Y}$ & & $\mathrm{Y}$ & & $\mathrm{Y}$ \\
\hline \multirow[t]{2}{*}{ Prov-Year-Track FE } & Y & $\mathrm{Y}$ & $\mathrm{Y}$ & $\mathrm{Y}$ & $\mathrm{Y}$ & Y & $\mathrm{Y}$ & Y \\
\hline & \multicolumn{2}{|c|}{ Graduate study } & \multicolumn{2}{|c|}{ Going abroad } & \multicolumn{2}{|c|}{ Waiting to decide } & \multicolumn{2}{|c|}{ Job Search } \\
\hline Above cutoff & $\begin{array}{c}0.007 \\
(0.018)\end{array}$ & $\begin{array}{l}-0.001 \\
(0.034)\end{array}$ & $\begin{array}{c}0.005 \\
(0.007)\end{array}$ & $\begin{array}{l}-0.001 \\
(0.011)\end{array}$ & $\begin{array}{c}0.028 * * \\
(0.013)\end{array}$ & $\begin{array}{c}0.037 \\
(0.023)\end{array}$ & $\begin{array}{l}-0.054 \\
(0.033)\end{array}$ & $\begin{array}{l}-0.032 \\
(0.050)\end{array}$ \\
\hline Observations & 10,335 & 10,335 & 10,335 & 10,335 & 10,335 & 10,335 & 10,335 & 10,335 \\
\hline R-squared & 0.095 & 0.199 & 0.051 & 0.063 & 0.050 & 0.130 & 0.082 & 0.121 \\
\hline
\end{tabular}

Note. This table reports results using the sample within the 20-point bandwidth. The results are obtained from parametric methods with quadratic controls while allowing for different slopes around the cutoff. Standard errors are two-way clustered at the college and province-year-track levels. Significance levels: $* 10 \%, * * 5 \%, * * * 1 \%$.

For weighted regressions, the weight is generated to reflect the population data, based on the population (administrative data) of all college students in 2003.

\section{C.2 Variation in the Wage Premium}

One may wonder wether the wage premium is mainly driven by above-cutoff students' having jobs in different industries, occupations, types of firm ownerships, or cities. To this end, we gradually include dummy variables for occupations, industries, types of ownership, and city location in our regression equation and check how the wage premium changes as a result. The estimates presented in Table C.2. The takeaway is that the wage premium cannot be washed away when we further include these characteristics. 
Table C.2: The Effect of Scoring above the Cutoff Score on First-job Wages: Controlling for Occupation, Industry, Ownership and Location

Dependent Variable: ln Wage

\begin{tabular}{|c|c|c|c|c|c|c|c|}
\hline & (1) & (2) & (3) & (4) & $(5)$ & $(6)$ & (7) \\
\hline Method & \multicolumn{7}{|c|}{ Parametric, Quadratic interaction controls } \\
\hline Weighted & & & & & & & Y \\
\hline Prov.-Year-Track FE & Y & $\mathrm{Y}$ & $\mathrm{Y}$ & Y & $\mathrm{Y}$ & $\mathrm{Y}$ & $\mathrm{Y}$ \\
\hline Occupation FEs (13) & & $\mathrm{Y}$ & & & & $\mathrm{Y}$ & Y \\
\hline Industry FEs (19) & & & Y & & & Y & $\mathrm{Y}$ \\
\hline Ownership FEs (4) & & & & $\mathrm{Y}$ & & Y & $\mathrm{Y}$ \\
\hline Job City FEs (286) & & & & & $\mathrm{Y}$ & $\mathrm{Y}$ & $\mathrm{Y}$ \\
\hline Above cutoff & $\begin{array}{c}0.067 * * \\
(0.027)\end{array}$ & $\begin{array}{c}0.075^{* *} * \\
(0.029)\end{array}$ & $\begin{array}{c}0.066^{* *} * \\
(0.025)\end{array}$ & $\begin{array}{c}0.064 * * \\
(0.026)\end{array}$ & $\begin{array}{c}0.061 * * \\
(0.029)\end{array}$ & $\begin{array}{c}0.065^{* *} * \\
(0.027)\end{array}$ & $\begin{array}{c}0.087 * * \\
(0.042)\end{array}$ \\
\hline Observations & 5,080 & 5,080 & 5,080 & 5,080 & 5,080 & 5,080 & 5,080 \\
\hline
\end{tabular}

Note. This table reports results using the sample within the 20-point bandwidth and with information on wages. The results are obtained from parametric methods with quadratic controls while allowing for different slopes around the cutoff. Standard errors are two-way clustered at the college and province-year-track levels. Significance levels: $* 10 \%$, $* * 5 \%, * * * 1 \%$.

For weighted regressions, the weight is generated to reflect the population data, based on the population (administrative data) of all college students in 2003.

\section{C.3 Bounding Exercises}

To assess the importance of missing wages, we employ the method provided by Lee (2009) to obtain bounding estimates. As reported in Columns (1)-(3) of C.3, we obtain reduced-form wage estimates ranging from $5.3 \%$ to $8.6 \%$. In addition, to further see how measurement errors in wages matter for our finding quantitatively, we trim the highest and lowest $10 \%$ in the wage distribution for the elite college graduates (within the 20-point bandwidth), assuming that the missing wages are the high and low ends. In addition to trimming the data based on the entire 20-point bandwidth, we further trim the data within 5 and 10 points around the cutoff. These results are reported Columns (4)-(9) in Table C.3, which are close to our baseline estimation. Due to the distribution of income, the number of observations can differ at the top or bottom 10\%. To avoid trimming unequal numbers of observations in the two tails, we remove equal number of observations when there are repeated observations. 
Table C.3: Bounding the Elite College Wage Premium

\begin{tabular}{|c|c|c|c|c|c|c|c|c|c|}
\hline & (1) & (2) & (3) & (4) & (5) & (6) & (7) & (8) & (9) \\
\hline Method & \multicolumn{9}{|c|}{ Parametric, Quadratic interaction controls } \\
\hline \multirow[t]{3}{*}{ Prov-Year-Track FE } & $\mathrm{Y}$ & $\mathrm{Y}$ & $\mathrm{Y}$ & $\mathrm{Y}$ & $\mathrm{Y}$ & $\mathrm{Y}$ & $\mathrm{Y}$ & $\mathrm{Y}$ & $\mathrm{Y}$ \\
\hline & & Lee & Lee & 20-point s & ample, elite & $\begin{array}{r}\text { Trim } \\
\text { 10-point } \mathrm{s}\end{array}$ & $\begin{array}{l}\text { data } \\
\text { mple, elite }\end{array}$ & 5-point sa & nple, elite \\
\hline & Baseline & Lower bound & Upper bound & top $10 \%$ & btm10\% & top $10 \%$ & btm10\% & top $10 \%$ & btm10\% \\
\hline Above cutoff & $\begin{array}{c}0.067 * * * \\
(0.009)\end{array}$ & $\begin{array}{c}0.053 * * * \\
(0.024)\end{array}$ & $\begin{array}{c}0.086^{* * * *} \\
(0.025)\end{array}$ & $\begin{array}{c}0.062^{* *} \\
(0.026)\end{array}$ & $\begin{array}{c}0.071^{* * *} \\
(0.026)\end{array}$ & $\begin{array}{c}0.069 * * * \\
(0.026)\end{array}$ & $\begin{array}{c}0.068 * * * \\
(0.026)\end{array}$ & $\begin{array}{c}0.064^{* *} \\
(0.026)\end{array}$ & $\begin{array}{c}0.071 * * * \\
(0.026)\end{array}$ \\
\hline Observations & 5,080 & 10,335 & 10,335 & 4,983 & 4,983 & 5,040 & 5,040 & 5,060 & 5,060 \\
\hline
\end{tabular}

Note. Columns (2)-(3) report the bounds following Lee (2009). Columns (4)-(9) report results using the sample within the 20-point bandwidth and with information on wages.

For the trimmed-data samples, the 20-point sample (Columns 4-5) means $[-20,+20]$ range around the cutoff score, the 10-point sample (Columns 6-7) means [-10, +10$]$ range around the cutoff score, and the 5-point sample (Columns 8-9) means $[-5,+5]$ range around the cutoff score. For each of these samples, we trip the top $10 \%$ or bottom $10 \%$ of the observations respectively. 


\section{C.4 Excluding Data in 2014 and 2015}

Our survey became voluntary in 2014 due to unexpected budget cuts, meaning only schools that could afford and were willing to participate in the survey were included in the 2014 and 2015 samples. The voluntary participation is less of a concern when using the weighted method. Nevertheless, to make sure our findings are not driven by this subsample, we exclude them in our analysis. As presented in Table C.4, the estimates for access to elite colleges and wage premium after excluding the data in 2014 and 2015 are close to what we obtain when using data for the entire period.

Table C.4: Elite College Wage Premium: Excluding Data in 2014 and 2015

\begin{tabular}{|c|c|c|c|c|c|}
\hline & (1) & $(2)$ & (3) & (4) & (5) \\
\hline $\begin{array}{l}\text { Method } \\
\text { Interaction controls } \\
\text { Weighted }\end{array}$ & Local Linear & $\begin{array}{c}\text { Parametric } \\
\text { Linear } \\
\text { y }\end{array}$ & $\begin{array}{l}\text { Parametric } \\
\text { Quadratic }\end{array}$ & $\begin{array}{c}\text { Parametric } \\
\text { Linear } \\
\text { Y } \\
\text { V }\end{array}$ & $\begin{array}{c}\text { Parametric } \\
\text { Quadratic } \\
\text { Y } \\
\text { V }\end{array}$ \\
\hline $\begin{array}{l}\text { Prov.-Year-Track FE } \\
\text { A. Dependent variable }\end{array}$ & & Y & $\begin{array}{r}\mathrm{Y} \\
\text { ln Wage }\end{array}$ & Y & Y \\
\hline Above cutoff & $\begin{array}{c}0.072 * * * \\
(0.025)\end{array}$ & $\begin{array}{c}0.075 * * * \\
(0.023)\end{array}$ & $\begin{array}{c}0.065 * * \\
(0.029)\end{array}$ & $\begin{array}{c}0.067 * * * \\
(0.025)\end{array}$ & $\begin{array}{c}0.094 * * \\
(0.043)\end{array}$ \\
\hline B. Dependent variable & \multicolumn{5}{|c|}{ Elite (National First-Tier) College } \\
\hline Above cutoff & $\begin{array}{c}0.172 * * * \\
(0.020)\end{array}$ & $\begin{array}{c}0.173 * * * \\
(0.065)\end{array}$ & $\begin{array}{c}0.155^{* * * *} \\
(0.055)\end{array}$ & $\begin{array}{c}0.207 * * * \\
(0.061)\end{array}$ & $\begin{array}{c}0.156^{* *} \\
(0.061)\end{array}$ \\
\hline C. Dependent variable & \multicolumn{5}{|c|}{ ln Wage } \\
\hline Elite college (instrumented) & $\begin{array}{c}0.420 * * * \\
(0.152)\end{array}$ & $\begin{array}{c}0.436 * * \\
(0.197)\end{array}$ & $\begin{array}{l}0.420^{*} \\
(0.239)\end{array}$ & $\begin{array}{l}0.323^{*} \\
(0.166)\end{array}$ & $\begin{array}{c}0.606 \\
(0.406)\end{array}$ \\
\hline Observations & 4,283 & 4,283 & 4,283 & 4,283 & 4,283 \\
\hline
\end{tabular}

Note. This table reports results using the sample within the 20-point bandwidth and with information on wages in our $2010-13$ survey. The results in Column (1) are obtained from the local linear method, and the other results are from parametric methods with linear or quadratic controls while allowing for different slopes around the cutoff. Standard errors for all parametric specifications are two-way clustered at the college and province-year-track levels. Significance levels: *10\%, **5\%, ***1\%.

For weighted regressions, the weight is generated to reflect the population data, based on the population (administrative data) of all college students in 2003 . 